\title{
Paleomagnetism of the Amazonian Craton and its role in paleocontinents
}

\author{
Paleomagnetismo do Cráton Amazônico \\ e sua participação em paleocontinentes
}

\author{
Manoel Souza D'Agrella-Filho ${ }^{1 *}$, Franklin Bispo-Santos ${ }^{1}$, \\ Ricardo Ivan Ferreira Trindade ${ }^{1}$, Paul Yves Jean Antonio ${ }^{1,2}$
}

\begin{abstract}
In the last decade, the participation of the Amazonian Craton on Precambrian supercontinents has been clarified thanks to a wealth of new paleomagnetic data. Paleo to Mesoproterozoic paleomagnetic data favored that the Amazonian Craton joined the Columbia supercontinent at $1780 \mathrm{Ma}$ ago, in a scenario that resembled the South AMerica and BAltica (SAMBA) configuration. Then, the mismatch of paleomagnetic poles within the Craton implied that either dextral transcurrent movements occurred between Guiana and Brazil-Central Shield after $1400 \mathrm{Ma}$ or internal rotation movements of the Amazonia-West African block took place between 1780 and $1400 \mathrm{Ma}$. The presently available late-Mesoproterozoic paleomagnetic data are compatible with two different scenarios for the Amazonian Craton in the Rodinia supercontinent. The first one involves an oblique collision of the Amazonian Craton with Laurentia at $1200 \mathrm{Ma}$ ago, starting at the present-day Texas location, followed by transcurrent movements, until the final collision of the Amazonian Craton with Baltica at ca. $1000 \mathrm{Ma}$. The second one requires drifting of the Amazonian Craton and Baltica away from the other components of Columbia after $1260 \mathrm{Ma}$, followed by clockwise rotation and collision of these blocks with Laurentia along Grenvillian Belt at 1000 Ma. Finally, although the time Amazonian Craton collided with the Central African block is yet very disputed, the few late Neoproterozoic/Cambrian paleomagnetic poles available for the Amazonian Craton, Laurentia and other West Gondwana blocks suggest that the Clymene Ocean separating these blocks has only closed at late Ediacaran to Cambrian times, after the Amazonian Craton rifted apart from Laurentia at ca. $570 \mathrm{Ma}$.
\end{abstract}

KEYWORDS: Amazonian Craton; paleomagnetism; supercontinents; Columbia; Rodinia; Gondwana.
RESUMO: Dados paleomagnéticos obtidos para o Cráton Amazônico nos últimos anos têm contribuido significativamente para elucidar a participação desta unidade cratônica na paleogeografia dos supercontinentes pré-cambrianos. Dados paleomagnéticos do Paleo-Mesoproterozoico favoreceram a inserção do Cráton Amazônico no supercontinente Columbia há $1780 \mathrm{Ma}$, em um cenário que se assemelhava à configuração "South AMerica and BAltica" (SAMBA). Estes mesmos dados também sugerem a ocorrência de movimentos transcorrentes dextrais entre os Escudos das Guianas e do Brasil-Central após $1400 \mathrm{Ma}$, ou que movimentos de rotação do bloco Amazônia-Oeste África ocorreram dentro do Columbia entre 1780 e $1400 \mathrm{Ma}$. Os dados paleomagnéticos atualmente disponiveis do final do Mesoproterozoico são compativeis com dois cenários diferentes para a Amazônia no supercontinente Rodinia. O primeiro cenário envolve uma colisão oblíqua da Amazônia com a Laurentia, começando no Texas há 1200 Ma, seguida por movimentos transcorrentes até o final da colisão da Amazônia com a Báltica há 1000 Ma. No segundo cenário, a ruptura da Amazônia e da Báltica do Columbia ocorre após 1260 Ma e é seguida por uma rotação horária e pela colisão desses blocos com a Laurentia ao longo do cinturão Grenville há 1000 Ma. Finalmente, a época em que a Amazônia colidiu com a parte central do Gondwana tem sido objeto de muita disputa. Todavia, os poucos polos paleomagnéticos do final do Neoproterozoico/Cambriano para o Cráton Amazônico, para a Laurentia e outros blocos do Gondwana Ocidental sugerem que o Oceano Clymene que separou estes blocos ocorreu entre o final dos periodos Ediacarano e Cambriano, após a separação do Cráton Amazônico da Laurentia há $570 \mathrm{Ma}$.

PALAVRAS-CHAVE: Cráton Amazônico; paleomagnetismo; supercontinentes; Columbia; Rodinia; Gondwana.

\footnotetext{
1Departamento de Geofísica, Instituto de Astronomia, Geofísica e Ciências Atmosféricas, Universidade de São Paulo (USP). E-mails: dagrella@iag.usp.br,frankb@ iag.usp.br, rtrindad@iag.usp.br

${ }^{2}$ Géosciences Environnement Toulouse (GET), Université de Toulouse, Observatoire Midi-Pyrénées, Toulouse, France. E-mail: paul@iag.usp.br

*Corresponding author.

Manuscript ID: 20160055. Received in: 04/15/2016. Approved in: 05/05/2016.
} 


\section{INTRODUCTION}

The paleogeography of continental blocks is the key piece of information to understand the geological evolution of our planet and the mechanisms that prevailed in the assembly and rupture of supercontinents, a process known as supercontinental cycle (Condie 2002). Based on the Pangea assembly, Meert (2012) defined that a supercontinent must comprise at least $75 \%$ of the existing continental crust. Based on this definition, the continental masses were united in supercontinents at least three times in Earth's history: $200 \mathrm{Ma}$ (Pangea), 1100-1000 Ma (Rodinia), and 1850$1800 \mathrm{Ma}$ (Columbia/NUNA). Note that large continental masses such as Gondwana and Laurasia did not comprise $75 \%$ of the continental surface, and therefore cannot be regarded supercontinents according to Meert's definition. The ages of assembly for the three supercontinents imply a periodicity of approximately $750 \mathrm{Ma}$ for the supercontinent cycle (Meert 2012).

If we consider the peaks in $\mathrm{U}-\mathrm{Pb}$ zircon ages, integrated with $\mathrm{Nd}$ isotopic ratios obtained for rocks all over the globe, we can assume the existence of a fourth supercontinent at ca. $2700 \mathrm{Ma}$ (Hawkesworth et al. 2010). However, the reconstruction of such Archean supercontinent is a challenge given the scarcity of paleomagnetically viable targets of that age (Evans 2013). Some attempts to correlate Archean units based on geological and paleomagnetic data have been published, such as the formation of Zingarn supercraton made by the link of Zimbabwe/Rhodesia (Africa) and Yilgarn (Australia) blocks (Smirnov et al. 2013), or the Vaalbara supercraton formed by Kaapvaal (Africa) and Pilbara (Australia) blocks (de Kock et al. 2009). However, the lack of the main paleomagnetic poles for the Archean nuclei make paleogeographic reconstructions for those times very speculative (Buchan et al. 2000, Pesonen et al. 2003).

Several paleogeographic reconstructions of a Paleoproterozoic supercontinent (1850-1800 Ma) have been proposed in literature (e.g. Rogers 1996, Rogers \& Santosh 2002, Zhao et al. 2002, 2003, 2004, 2006, Meert 2002, Pesonen et al. 2003, Hou et al. 2008a, 2008b, Johansson 2009, 2014, Yakubchuck 2010, Piper 2010, Evans \& Mitchell 2011, Zhang et al. 2012, among others). This supercontinent has received different names: NENA (Gower et al. 1990), NUNA (Hoffman 1997), Columbia (Rogers \& Santosh 2002), or Paleopangea (Piper 2010). Reddy \& Evans (2009) advocate the name NUNA because it is older than the name Columbia. However, Meert (2012) argues that the NUNA paleocontinent defined by Hoffman (1997) differs little from the NENA proposed by Gower $e t$ al. (1990). Therefore, if precedence should be considered, this Mesoproterozoic supercontinent should be named
NENA. In addition, NENA and NUNA originally refer to correlations between Laurentia, Baltica, Siberia, and eventually East Antarctica, so these reconstructions represent only a fraction of the Paleoproterozoic supercontinent. In this way, Meert (2012) states that the name Columbia proposed by Rogers \& Santosh (2002) designates the first attempt of a global and testable reconstruction. After Meert's (2012) reasonings, we will call hereafter the Paleoproterozoic supercontinent as Columbia.

The rupture time of Columbia is a subject of intense discussion in literature. Some authors suggest that Columbia broke-up soon after its formation, as evidenced by the significant amount of mafic dykes dated around 1780-1790 Ma found in North China Craton (Kusky et al. 2007), Baltica (Pisarevsky \& Bylund 2010), and Amazonian Craton (Reis et al. 2013). Nevertheless, such global tectonic and magmatic features are usually associated with Statherian taphrogenesis at different cratons, and so they would not represent a complete rupture of the supercontinent (Brito Neves et al. 1995). Indeed, paleomagnetic and geochronological data obtained for Baltica and Laurentia, which formed the Columbia core (e.g. Zhao et al. 2002), suggest they remained joined from $1800 \mathrm{Ma}$ until at least $1270 \mathrm{Ma}$ (Salminen \& Pesonen 2007). A long-lived Columbia is consistent with the unusual tectonic style that prevailed in the Mesoproterozoic, marked by a strong decrease in the subduction flow and subduction related magmatism (Silver \& Behn 2008). This is also coherent with the intense intracratonic magmatic activity that is characterized by the emplacement of a voluminous anorogenic rapakivi granitic magmatism, between 1600 and $1300 \mathrm{Ma}$, which is one of the most striking features of the continental blocks forming Columbia (e.g. Åhäll \& Connelly 1998, Anderson \& Morrison 1992, Bettencourt et al. 1999, Hoffman 1989, Karlstrom et al. 2001, Rämö et al. 2003, Vigneresse 2005).

Piper (2010) proposes that the demise of Columbia occurred through a series of small intracratonic rotations that are consistent with $\mathrm{U}-\mathrm{Pb}$ ages (and Nd model ages), obtained for rocks between 1200 and $1000 \mathrm{Ma}$. Such period is characterized by a small peak in the formation of juvenile crust, when compared with periods related to the formation of other supercontinents (Hawkesworth et al. 2010). Recently, Pisarevsky et al. (2014) suggested that the Columbia supercontinent began its agglutination at $-1700 \mathrm{Ma}$, reaching its maximum area between 1650-1580 Ma. They also argued that Columbia broke-up in two stages. The first one occurred between 1450 and $1380 \mathrm{Ma}$ and the second at ca. $1270 \mathrm{Ma}$. In contrast, Zhao et al. (2004) and Rogers \& Santosh (2009) postulated that Columbia's break-up occurred almost synchronously at ca. $1500 \mathrm{Ma}$.

Almost all continental masses involved in Columbia, later assembled to form the Rodinia supercontinent at about 
1100 - 1000 Ma ago (McMenamin \& McMenamin 1990). Several paleogeographic reconstructions have been proposed for the Neoproterozoic supercontinent (e.g. Hoffman 1991, Weil et al. 1998, D’Agrella-Filho et al. 1998, Dalziel et al. 2000, Tohver et al. 2002, 2006, Pisarevsky et al. 2003, Meert \& Torsvik 2003, Li et al. 2008). Li et al. (2008) rebuilt Rodinia including all cratonic areas of the world. However, geological evidence show that some continental blocks that formed the West Gondwana (e.g. Congo-São Francisco, Kalahari) did not take part in Rodinia, since a large ocean existed between these units and the Amazonian Craton (Cordani et al. 2003, Kröner \& Cordani 2003, D'Agrella-Filho et al. 2004, and references therein). After Rodinia break-up, their continental fragments gathered in other configurations (e.g. Gondwana), but the details of this process, including the timing and reassembly configuration of the different blocks, are still a subject of debate in literature, mainly due to the almost total absence of key paleomagnetic poles between 900 and $600 \mathrm{Ma}$ for the units that potentially composed these landmasses.

The Amazonian Craton, in the Northwest of South America, surely played a fundamental role in the Earth's geodynamic history and in the paleogeography of Columbia, Rodinia, and Gondwana. In recent years, a wealth of new paleomagnetic data was obtained for this unit with important implications on the formation and rupture of Columbia and Rodinia supercontinents, and on the agglutination of Gondwana. In Table 1, we list all poles between 2100 and $530 \mathrm{Ma}$ available for the Amazonian Craton and corresponding references.

In this paper, we will discuss the recent paleomagnetic and geological evidence for the participation of the Amazonian Craton in different Proterozoic supercontinents. Firstly, we will introduce the reasoning behind paleogeographic reconstructions based on paleomagnetic data. Then, we will present a brief description of the geologic/tectonic compartments of the Amazonian Craton. The following topics discuss the recent paleomagnetic data and their implications for the participation of the Amazonian Craton in pre-Columbia times, in Columbia supercontinent, in Rodinia supercontinent, and in the Gondwana continent. Finally, the most important conclusions regarding the geodynamic evolution of the Amazonian Craton during the Proterozoic will be shown.

\section{PALEOMAGNETIC RECONSTRUCTION OF PALEOCONTINENTS}

The Pangea was the first supercontinent to be reconstructed on the basis of the fitting of geological provinces, continent shorelines, paleoclimatic indicators, and the continuity of the paleontological record throughout the ancient continental assembly (Wegener 1912). With the advent of isotope geochemistry, radiometric chronology and geophysics, other approaches were incorporated into the exercises of paleocontinent reconstructions, particularly the pre-Pangea supercontinents (Evans 2013), including the age and continuity of large igneous provinces and paleomagnetic data. From these, the only technique that provides a quantitatve assessment of the past distribution of the continents is paleomagnetism (e.g. Butler 1992).

Paleomagnetic poles are equated to the Earth's spinning poles and therefore provide a geographical reference frame for reconstructions. The paleomagnetic method is based on two premises:

1. the Earth's magnetic field when averaged over $10^{4}$ to $10^{5}$ years is equivalent to that of a dipole centered in the planet, and aligned along its rotation axis;

2. magnetic minerals record and preserve the orientation of the ancient field over geological time scales.

The first premise is also known as the geocentric axial dipole (GAD) hypothesis, and seems to hold for recent and ancient times (Meert 2009, Swanson-Hysell et al. 2009). The field sampling must then comprise sites distributed within at least tens to hundreds of thousand years. This is the reason why several dykes or sedimentary strata must be sampled to determine a single paleomagnetic pole.

For ensuring that a paleomagnetic pole calculated for a given geological formation fits the GAD assumption, we must comply with minimum statistical standards (e.g. number of samples larger than 24; confidence circle around the pole smaller than $16^{\circ}$; van der Voo 1990). In addition, paleomagnetic directions for a given target must preferentially include normal and reversed directions, thus proving that enough time has elapsed during the eruption, intrusion or deposition of the studied geological unit. The second premise of paleomagnetism assumes that the orientation of the geomagnetic field, when the rock unit was formed, is preserved until today in its magnetic remanence vector. However, we know that different geological processes, such as metamorphism or diagenesis, can change the original magnetization by re-heating original magnetic grains or creating new ones (van der Voo \& Torsvik 2012). Usually, this change overprints the original magnetization only partially and a single sample may therefore record two or more remanence vectors.

Classically, we apply the stepwise demagnetization techniques to deconvolve the different components of the natural remanence vector; the remanence unblocked in more stable magnetic grains is usually interpreted as the primary one (As \& Zijderveld 1958). In order to attest to the primary 
Table 1. Paleomagnetic poles from the Amazonian Craton between 2100 and 530 Ma.

\begin{tabular}{|c|c|c|c|c|c|c|}
\hline Rock unit & Plat $\left({ }^{\circ} \mathbf{N}\right)$ & Plong $\left({ }^{\circ} \mathrm{E}\right)$ & $\mathrm{d}_{\mathrm{p}} / \mathrm{d}_{\mathrm{m}}\left(\mathrm{(}^{\circ}\right)$ & Age \pm error $(\mathrm{Ma})$ & $\mathbf{Q}$ & Ref. \\
\hline \multicolumn{7}{|l|}{ The proto-Amazonian Craton before Columbia } \\
\hline a) Tumuc Humac Mount. Granite & 18.9 & 273.7 & $19.2 / 22.3$ & $2100 \pm 1 \mathrm{U}-\mathrm{Pb} \mathrm{zrn}$ & 3 & 1,2 \\
\hline b) Tampok River Granite & -6.9 & 300.1 & 15.9/16.1 & $2155 \pm 3 \mathrm{U}-\mathrm{Pb}$ zrn & 3 & 1,3 \\
\hline c) Mataroni River Granite & 14.9 & 289.2 & $40.6 / 42.7$ & $2115 \pm 3$ U-Pb zrn & 3 & 1,2 \\
\hline d) Approuague River Granite & 4.5 & 298.9 & 19.1/19.2 & $2093 \pm 3 \mathrm{U}-\mathrm{Pb} \mathrm{zrn}$ & 3 & 1,2 \\
\hline e) Approuague River Granite & -5.9 & 296.9 & $34.3 / 35.1$ & $2100-2050$ & 3 & 1 \\
\hline f) Approuague River Granodiorite & -18.5 & 294.3 & $21.3 / 23.0$ & $2089 \pm 4$ U-Pb zrn & 3 & 1,3 \\
\hline g) Approuague River Granite & 5.3 & 293.4 & $16.8 / 17.2$ & 2050-2070 & 3 & 1 \\
\hline Mean (a-g) - GF1 pole & 1.8 & 292.5 & $(11.2)$ & $2050-2070$ & 3 & 4 \\
\hline h) Oyapok granitoids - OYA pole & -28.0 & 346.0 & $(13.8)$ & $\begin{array}{c}2036 \pm 14 \mathrm{Ar}-\mathrm{Ar} \\
\mathrm{amp}\end{array}$ & 5 & 1,5 \\
\hline i) Armontabo River Granite - ARMO pole & -2.7 & 346,3 & $(14.2)$ & $2080 \pm 4$ U-Pb zrn & 4 & 1,6 \\
\hline j) Imataca Complex - IM1 pole & -49.0 & 18.0 & $(18.0)$ & $1960-2050$ & 3 & 7 \\
\hline k) Imataca Complex - IM2 pole & -29.0 & 21.0 & $(18.0)$ & 1960-2050 & 3 & 7 \\
\hline l) Encrucijada Pluton - EN1 pole & -55.0 & 8.0 & $(6.0)$ & $\begin{array}{c}1972 \pm 4 \mathrm{Ar}-\mathrm{Ar} \\
\mathrm{amp}\end{array}$ & 3 & 8 \\
\hline m) Encrucijada Pluton - EN2 pole & -37.0 & 36.0 & $(18)$ & $\begin{array}{c}1972 \pm 4 \mathrm{Ar}-\mathrm{Ar} \\
\mathrm{amp}\end{array}$ & 3 & 8 \\
\hline Mean (h-m) - CA1 pole & 43.2 & 21.9 & $(16,5)$ & $\sim 1970$ & 3 & 9 \\
\hline n) Costal Late Granite - PESA pole & -56.7 & 25.1 & $6.2 / 12.4$ & $2060 \pm 4 \mathrm{U}-\mathrm{Pb}$ zrn & 3 & 1,3 \\
\hline o) Costal Late Granite - ROCO pole & -58.0 & 26.4 & $7.9 / 15.8$ & $2095 \pm 6$ U-Pb zrn & 3 & 1,3 \\
\hline p) Costal Late Granite - MATI pole & -58.6 & 25,5 & $9.7 / 19.4$ & $\sim 2050-1970$ & 3 & 1 \\
\hline q) Costal Late Granite - ORGA pole & -59.7 & 44.7 & $10.1 / 19.5$ & $2069 \pm 4$ U-Pb zrn & 3 & 1,3 \\
\hline Mean (n-q) - GF2 pole & -58.5 & 30.2 & $(5.8)$ & $\sim 2050-1970$ & 3 & 4 \\
\hline Roraima Uairen Fm. - U2 pole & -66.5 & 9.0 & $(17.8)$ & $1920-1830$ & 2 & $\begin{array}{l}10, \\
11\end{array}$ \\
\hline Surumu Group volcanics - SG pole & -27.4 & 54.8 & $(9.8)$ & $1966 \pm 9 \mathrm{U}-\mathrm{Pb}$ zrn & 5 & $\begin{array}{c}9, \\
12, \\
13\end{array}$ \\
\hline \multicolumn{7}{|c|}{ The Amazonian Craton in the Columbia supercontinent } \\
\hline Roraima Uairen Fm. - U1 pole & -69.0 & 17.0 & $(7.2)$ & $1838 \pm 14 \mathrm{U}-\mathrm{Pb}$ fl & 4 & $\begin{array}{l}10, \\
11\end{array}$ \\
\hline Aro-Guaniamo dike (group II) & -42.0 & 0.0 & $(6.0)$ & $\begin{array}{c}1820 \text { mean } \mathrm{Ar}-\mathrm{Ar} \\
\mathrm{bi}\end{array}$ & 4 & 8 \\
\hline Colider Group (rhyolites) - CG pole & -63.3 & 298.8 & $(10.2)$ & $1789 \pm 7 \mathrm{U}-\mathrm{Pb}$ zrn & 4 & 14 \\
\hline Avanavero Sills - AV pole & -48.4 & 27.9 & (9.6) & $\begin{array}{c}1788.5 \pm 2.5 \mathrm{U}-\mathrm{Pb} \\
\text { badd }\end{array}$ & 5 & $\begin{array}{l}15, \\
16\end{array}$ \\
\hline Basic dykes (group I) & 59.0 & 222.0 & $(6.0)$ & $1800-1500$ & 4 & 8 \\
\hline Kabaledo dykes & 44.0 & 210.0 & $(14.3)$ & $1800-1500$ & 2 & 17 \\
\hline La Escalera basic dykes (group 1) & 55.5 & 225.5 & $(11.2)$ & $1800-1500$ & 4 & 8 \\
\hline Parguaza G3N & 10.7 & 294.7 & $(25.0)$ & $1545-1393$ & 1 & $\begin{array}{l}18, \\
19, \\
20\end{array}$ \\
\hline Parguaza rapakivi batholith G1R & 54.4 & 173.7 & (9.6) & $1545-1392$ & 1 & $\begin{array}{l}18, \\
19, \\
20\end{array}$ \\
\hline Mean Mucajai/Parguaza complex & 31.7 & 186.6 & $(22.8)$ & $\sim 1530$ & 2 & 21 \\
\hline
\end{tabular}


Tabela 1. Continuation.

\begin{tabular}{|c|c|c|c|c|c|c|}
\hline Rock unit & Plat $\left({ }^{\circ} \mathbf{N}\right)$ & Plong $\left({ }^{\circ} \mathrm{E}\right)$ & $\mathrm{d}_{\mathrm{p}} / \mathrm{d}_{\mathrm{m}}\left(\mathrm{A}^{\circ}\right)$ & Age \pm error $(\mathbf{M a})$ & $\mathbf{Q}$ & Ref. \\
\hline Guadalupe Gabbro (Component A) & 38.9 & 306.2 & $(13.7)$ & $1531 \pm 16 \mathrm{U}-\mathrm{Pb}$ zrn & 4 & 22 \\
\hline Roraima dolerites, younger component & 63.0 & 231.0 & $(8.8)$ & $1468 \pm 3 \mathrm{Ar}-\mathrm{Ar} \mathrm{pl}$ & 2 & 8 \\
\hline Rio Branco sedimentary rocks - A1 pole & -45.5 & 270.0 & (6.5) & $1440-1544 \mathrm{U}-\mathrm{Pb}$ & 4 & $\begin{array}{l}23 \\
24\end{array}$ \\
\hline Salto do Céu sills - A2 pole & -56.0 & 278.5 & (7.9) & $\begin{array}{c}1439 \pm 4 \text { U-Pb } \\
\text { badd; } 981 \pm 2 \text { Ar- } \\
\text { Ar wr }\end{array}$ & 5 & $\begin{array}{l}23 \\
25 \\
26\end{array}$ \\
\hline Nova Guarita dykes - A3 pole & -47.9 & 245.9 & (7.0) & $\begin{array}{c}1418.5 \pm 3.5 \mathrm{Ar}- \\
\mathrm{Ar} \mathrm{bi}\end{array}$ & 6 & 27 \\
\hline Indiavai dykes - $\mathrm{A} 4$ pole & -57.0 & 249.7 & (8.6) & $\begin{array}{c}1415.9 \pm 6.9 \mathrm{U}-\mathrm{Pb} \\
\mathrm{zrn}\end{array}$ & 4 & $\begin{array}{l}28 \\
29\end{array}$ \\
\hline Nova Lacerda mafic dykes & -0.5 & 310.7 & (17.9) & $1380 \pm 32 \mathrm{Rb}-\mathrm{Sr}$ & 2 & $\begin{array}{l}30 \\
31\end{array}$ \\
\hline \multicolumn{7}{|c|}{ The Amazonian Craton: Rodinia's prodigal son } \\
\hline Nova Floresta formation - NF pole & 24.6 & 164.6 & $(6.2)$ & $1198 \pm 3 \mathrm{Ar}-\mathrm{Ar}$ bi & 5 & 32 \\
\hline Fortuna formation - FT pole & 59.8 & 155.9 & (9.5) & $1149 \pm 7 \mathrm{U}-\mathrm{Pb} x$ & 5 & 33 \\
\hline \multicolumn{7}{|l|}{ The Amazonian Craton in Gondwana } \\
\hline Puga Cap carbonate - A pole & -82.6 & 292.6 & $(7.2)$ & $627 \pm 30 \mathrm{~Pb}-\mathrm{Pb}$ wr & 4 & 34 \\
\hline Puga Cap carbonate - B pole & 33.6 & 326.9 & $(8.4)$ & $530-520^{*}$ & 2 & 34 \\
\hline
\end{tabular}

Plat: Paleolatitude; Plong: Paleolongitude; $d / d_{m}\left(A_{95}\right)$ (in degrees): Fisher's statistical parameters. Geochronological symbols - zrn: zircon; badd: baddeleyite; bi: biotite; pl: plagioclase; fl: fluorapatite; x: xenotime; amp: amphibole; wr: whole rock; Q: quality factor (van der Voo 1990); *: inferred from the Gondwana apparent polar wander path. References of the table: 1 - Théveniaut et al. (2006); 2 - Vanderhaeghe et al. (1998); 3 - Delor et al. (2003); 4 - D’Agrella-Filho et al. (2011); 5 - Nomade et al. (2001); 6 - Enjolvy (2004); 7 - Onstott \& Hargraves (1981); 8 - Onstott et al. (1984a); 9 - Bispo-Santos et al. (2014a); 10 Castillo \& Costanzo-Alvarez (1993); 11 - Beyer et al. (2015); 12 - Fraga \& Dreher (2010); 13 - Schobbenhaus et al. (1994); 14 - Bispo-Santos et al. (2008); 15 - Bispo-Santos et al. (2014b); 16 - Reis et al. (2013); 17 - Veldkamp et al. (1971); 18 - Valdespino \& Costanzo-Alvarez (1997); 19 - Gaudette et al. (1978); 20 - Bonilla-Pérez et al. (2013); 21 - Veikkolainen et al. (2011); 22 - Bispo-Santos (2012); 23 - D’Agrella-Filho et al. (2016); 24 - Geraldes et al. (2014); 25 - Teixeira et al. (2016); 26 - Elming et al. (2009); 27 - Bispo-Santos et al. (2012); 28 - D’Agrella-Filho et al. (2012); 29 - Teixeira et al. (2011); 30 - Tamura et al. (2013); 31 - Girardi et al. (2012); 32 - Tohver et al. (2002); 33 - D’Agrella-Filho et al. (2008); 34 - Trindade et al. (2003).

nature of a remanence direction, we use paleomagnetic stability tests, such as the baked contact test, the fold test, and the conglomerate test (see details in Butler 1992). In addition, the direction must be different from the paleomagnetic directions obtained in younger geological units of the same region. van der Voo (1990) summarized the checks conceived to attest if the two basic assumptions of paleomagnetism were valid. Furthemore, van der Voo stablished that a reference paleomagnetic pole must have been obtained in a geological unit in structural continuity to the cratonic block and must have a precise dating (error within $4 \%$ ).

With reference paleomagnetic poles in hand, one can define the ancient position of continents based on their Euler rotations. The Euler theorem implies that any displacement in the surface of a sphere is equivalent to a single rotation about a fixed axis. Thus, to drive any continental mass back to its ancient position, we just need a rotation pole and the rotation angle around it. In this way, the confirguration of a paleocontinent can be expressed as a series of rotation poles and angles and as such they can be tested with new paleomagnetic poles or through the other approaches cited before.
Euler pole reconstructions of continent motions date back to the work of Bullard et al. (1965), but until recently several reconstructions are still performed by cutting and pasting continents on flat maps, thus distorting their contours and providing models that are sometimes unrealistic and not testable. Nowadays, several softwares enable to easily reconstruct the global geography in three-dimensions using rotation angles and poles (e.g. GPlates, Williams et al. 2012, GMap, Torsvik \& Smethurst 1999).

The paleomagnetic approach to paleocontinent reconstructions has nevertheless some drawbacks: the most important is the ambiguity in polarity given the axial symmetry of the GAD model (Fig. 1). Because of that, a paleomagnetic pole allows one to assign a paleolatitude and a paleodeclination (rotation from present-day North) for a continent but not the hemisphere or longitude it belonged to in the past. Therefore, to deduce the paleolongitude and polarity of different continental masses in paleogeographic reconstructions, one must use additional information other than paleomagnetism. In the further discussion, we attempted to complement the paleomagnetic information for the 


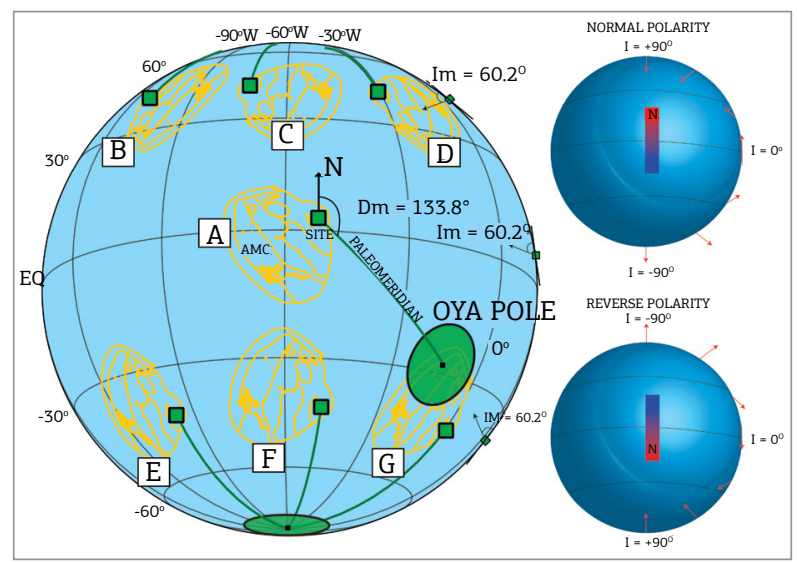

Figure 1. Amazonian craton (AMC) and geologic/ geocronological provinces (yellow lines) reconstructed with the OYA pole. Amazonian craton is shown in its present position $(\mathrm{A})$ with South American coastline. Also shown is the local geographic position of the Oyapok granites and their respective pole (with confidence circle) in green. Paleomeridian line passing through the sampling site and paleomagnetic pole is also shown. Positions $\mathrm{B}$ to $\mathrm{G}$ show that the continent can be moved freely along the same latitude for the two choices of polarity: Normal (B, C and D) or Reverse (E, F and G). $D_{m}$ and $I_{m}$ are, respectively, the mean declination and inclination of characteristic remanent magnetization direction calculated for the OYA rocks. "Normal polarity" and "reverse polarity" globes on the right show the configuration of inclination (I, red arrows) for each case.
Amazonia Craton and surrounding cratonic blocks with the most updated geological data available in the literature.

\section{THE AMAZONIAN CRATON}

The Amazonian Craton is one of the largest cratonic areas in the world, with about four million square kilometers (Fig. 2a). It is exposed in two major areas divided by the Phanerozoic Amazon Basin: the Guiana Shield to the North and the Brazil-Central Shield (also known as Guaporé Shield) to the South (Schobbenhaus et al. 1984, Santos et al. 2000, Lacerda-Filho et al. 2004). According to recent syntheses of Tassinari et al. (2000), Delor et al. (2003), Santos et al. (2003), and Cordani \& Teixeira (2007), the evolution of the Amazonian Craton is marked by successive accretionary events with greater or lesser involvement of the juvenile crust occurred from the Paleoproterozoic to the Neoproterozoic.

Based on geochronological data, Tassinari \& Macambira (1999, 2004) proposed an evolutionary model for the Amazonian Craton, which began when Hadean-Archean microcontinents assembled along Paleoproterozoic collisional orogens between $2200 \mathrm{Ma}$ and $1950 \mathrm{Ma}$. This was followed by the development of a succession of magmatic arcs and collisional processes involving the reactivation and reworking of pre-existing rocks. Two models that subdivide
A

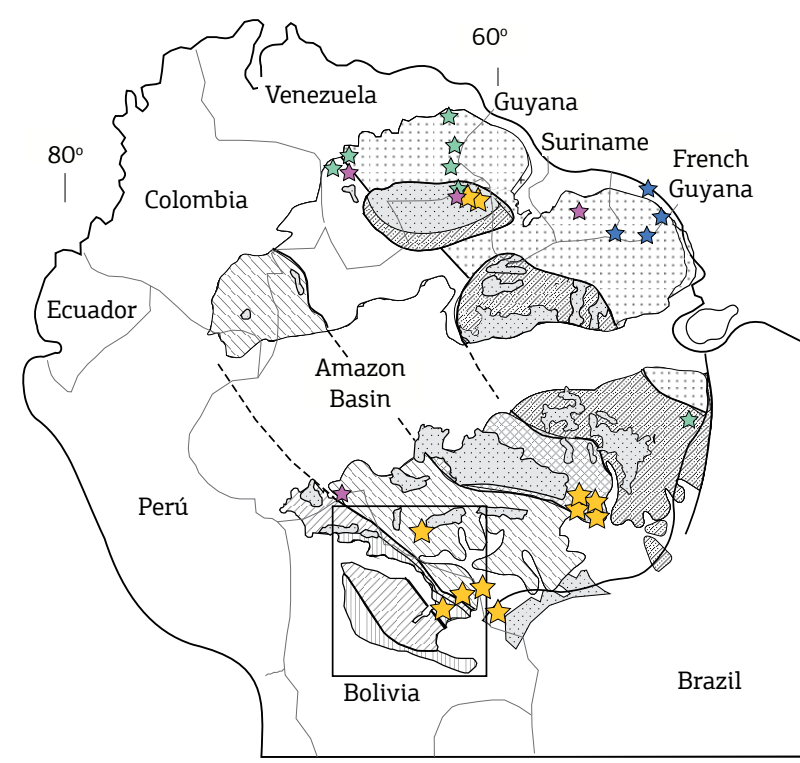

B
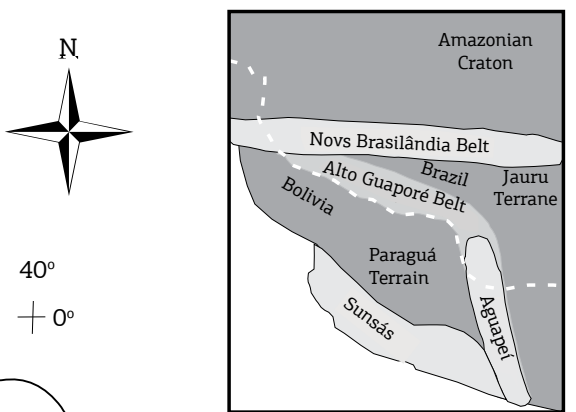

IAG Group (1979-present)

BRGM Group (2001-2006)

Princeton Group (1981-1990) Other groups

Phanerozoic sedimentary covers

Precambrian Sedimentary Covers

Central Amazonian Province (> 2,6 GA)

Maroni-Itacaiunas Province (2,25-2,05 Ga)

ntuari-Tapajós Province (1,98-1,88 Ga)

o Negro-Juruena Province (1,78-1,55 Ga)

$20^{\circ}$

Figure 2. (A) Amazonian Craton and their geologic/geochronological provinces (adapted from Cordani \& Teixeira 2007 and Bettencourt et al. 2010). The stars indicate approximate geographical locations of geological units studied by the following research groups: Princeton - blue; BRGM - green; IAG-USP - yellow; other groups purple. (B) Sketch of the southwestern part of the Amazonian Craton showing Paraguá Terrain and Alto Guaporé, Sunsás, Aguapeí, and Nova Brasilândia belts (modified after D’Agrella-Filho et al. 2012). 
the Amazonian Craton into geochronological provinces have been proposed, one by Tassinari \& Macambira (1999, 2004) and the other by Santos et al. (2003). We followed the model of Tassinari \& Macambira (1999, 2004) (Fig. 2A), which is adopted by several other authors (e.g. Schobbenhaus et al. 2004, Cordani \& Teixeira 2007, Cordani et al. 2010, Bettencourt et al. 2010).

The oldest portion (Hadean-Archean) of the Amazonian Craton (Central Amazonian Province) consists of granite-greenstone terrains and high-grade metamorphic rocks exposed in the Brazil-Central and Guiana shields (Tassinari \& Macambira 2004, Nadeau et al. 2013). The MaroniItacaiúnas Belt separates these landmasses, and it is dated around 2250-2050 Ma (Ledru et al. 1994). The HadeanArchean basement is covered by volcano-sedimentary sequences with little or no deformation and ages ranging between 1980 and $1400 \mathrm{Ma}$. The southwestern part of the Hadean-Archean core was accreted by subduction-related juvenile magmatic arcs, which formed the Ventuari-Tapajós (1980-1810 Ma) and Rio Negro-Juruena (1780 - 1550 Ma) Provinces (Tassinari \& Macambira 1999, Tassinari et al. 2000, Pinho et al. 2003, Schobbenhaus \& Brito Neves 2003, Cordani \& Teixeira 2007).

During the Mesoproterozoic, subduction-related magmatic arcs were developed between $1600 \mathrm{Ma}$ and $1300 \mathrm{Ma}$ (e.g. Jauru Terrain in Mato Grosso State), forming the Rondoniano-San-Ignacio Province until the final collision of Paraguá Terrain at about $1320 \mathrm{Ma}$ ago (Bettencourt et al. 2010). This collisional model has been extended to the northwestern Rondonia State, with the recognition of the Trincheira ophiolite by Rizzotto \& Hartmann (2012), who interpreted it as an oceanic crust fragment raised during the Mesoproterozoic as a consequence of the collision between the Paraguá Terrain and the proto-Amazonian Craton along the Alto Guaporé Belt (Fig. 2B). The E-W Nova Brasilândia Belt (NBB - 1100 - 1000 Ma old) at North of the Paraguá Terrain (Fig. 2b) most likely represents intracratonic reactivations that occurred during the development of Sunsás orogen (Sunsás Province - $1250-1000 \mathrm{Ma}$ ), which is located on the southwestern tip of the Amazonian Craton, in the Bolivian region (Litherland et al. 1989, Boger et al. 2005, Santos et al. 2008, Teixeira et al. 2010, Cordani et al. 2010). Some authors, however, interpret the NBB as a result of the collision between the proto-Amazonian Craton and the Paraguá Terrain, which would extend to Mato Grosso State, including the Jauru Terrain (Tohver et al. 2004a).

The Aguapei Belt (Fig. 2B) is considered a branch to the north of the Sunsas belt, separated from the main part of the orogeny by the Paraguá Terrain. This belt has been interpreted as an aborted continental rift, whose deposition initiated at ca. $1300 \mathrm{Ma}$, followed by compression and thrusting to the east at ca. $1000 \mathrm{Ma}$ (Litherland et al. 1989, Sadowski \& Bittencourt 1996).

\section{THE PROTO-AMAZONIAN CRATON BEFORE COLUMBIA}

The definition of a crustal paleogeography for the period prior to Columbia formation is yet very speculative, since many continental blocks were still being assembled during this period, including the Amazonian Craton, Laurentia, and Baltica. Well-dated paleomagnetic poles for the different fragments that later were assembled in these cratons are scarce, thus we can only speculate about the possible presence of Archean supercratons, as are the cases of Zingarn (Zimbabwe/Rhodesia/Yilgarn) and Vaalbara (Kaapvaal/ Pilbara) supercratons proposed by Smirnov et al. (2013) and de Kock et al. (2009), respectively. In Amazonia, some authors advocate a relation between the Guiana Shield and the West Africa Craton forming a single, large cratonic block (supercraton) at about $2000 \mathrm{Ma}$ ago (Onstott \& Hargraves 1981, Nomade et al. 2003, Johansson 2009, Evans \& Mitchell 2011).

Despite the general scarcity of Precambrian paleomagnetic data for the Amazonian Craton, the interval between 2100 and $1970 \mathrm{Ma}$ is relatively well represented in the database as a result of studies carried out by two research groups at different times. These studies led to the construction of apparent polar wander paths (APW Paths) for the Amazonian Craton (Guiana Shield) and the West Africa Craton for Orosirian times. In the 1980s, the Princeton group (led by Tullis C. Onstott) conducted a series of paleomagnetic and geochronological studies on intrusive rocks from Guiana Shield (Venezuela and Guyana; see localizations of the studied geological units in Fig. 2 - green stars) and West Africa Craton (Onstott \& Hargraves 1981, Onstott et al. 1984a, 1984b). Based on the available paleomagnetic data, these authors argued that Guiana Shield was an extension of West Africa Craton, however, it was displaced in relation to the Pangaea reconstruction in such way that the Guri lineament in Guiana Shield and Sassandra lineament in West Africa Craton were aligned (Onstott \& Hargraves 1981).

In the beginning of the last decade, researchers from the Bureau de Recherches Géologiques et Minières (BRGM, in France) extended the studies of the Princeton group using granitic and metavolcanic rocks exposed in the French Guiana (see localizations of studied geological units in Fig. 2 - blue stars), and also from West Africa Craton (Nomade et al. 2001, 2003). APW Paths were constructed for West Africa Craton and Guiana Shield for the time interval 2100 - 1990 Ma (Nomade et al. 2003). Such authors showed that both 
APW Paths overlap at about $2020 \mathrm{Ma}$, if the paleogeographic configuration suggested by Onstott \& Hargraves (1981) was used. Subsequently, Théveniaut et al. (2006), also from the BRGM, presented a comprehensive paleomagnetic and geochronological study regarding plutonic and metamorphic rocks from Guiana Shield, in which they tried to accurately identify the age of magnetization acquisition of the studied rocks, based on several U-Pb and Ar-Ar datings of minerals with different closure temperatures. According to a new group of poles and the reinterpretation of previous paleomagnetic poles, Théveniaut et al. (2006) proposed a new APW Path for the Amazonian Craton (Guiana Shield), between 2155 and $1970 \mathrm{Ma}$. However, they did not discuss the paleogeography proposed by Onstott \& Hargraves (1981), which was corroborated by Nomade et al. (2003).

Recently, new paleomagnetic data were obtained for felsic volcanic rocks from the Surumu Group (Guiana Shield), which is well dated at 1960-1980 Ma by the U-Pb method (Bispo-Santos et al. 2014a). A robust paleomagnetic pole (Tab. 1) was obtained for these rocks, which helps to better define the APW Path traced by Théveniaut et al. (2006) between 2070 and 1970 Ma for the Guiana Shield (Fig. 3). This APW Path began being defined by a series of paleopoles concentrated on northern South America, which Théveniaut et al. (2006) associated with the Orosirian deformation event (2070-2050 Ma) that affected the French Guiana. An average paleopole designated GF1 (Fig. 3, Tab. 1) was determined for this set of poles (D'Agrella-Filho et al. 2011). Eastward, the curve passes over the ARMO and OYA poles (Tab. 1) determined for granites collected over the Armontabo and Oyapok rivers, respectively, whose first letters provided the acronyms of their poles. The age of these poles was defined by dating different minerals (zircon, amphibole and biotite) representing distinct closure temperatures associated with their isotopic systems.

Théveniaut et al. (2006) interpret the $2020 \pm 4 \mathrm{Ma}$ Ar-Ar age (amphibole) obtained for an Oyapok River granite as the one that best agrees with the blocking temperature of the magnetic mineral (magnetite), which records the geomagnetic field at the time of formation of these rocks, which yielded the OYA pole. The youngest part of the curve is established by two sets of poles: the first corresponds to the poles determined for the Imataca Complex (IM1, IM2 - Tab. 1) and the La Encruzijada Granite (EN1, EN2 - Tab. 1), which are integrated into a single average paleopole called CA1 (Fig. 3, Tab. 1). The second set comprises four poles determined for granitic rocks of northern French Guiana (Théveviaut et al. 2006), whose average is represented by GF2 (Fig. 3, Tab. 1). An approximate age of $1970 \mathrm{Ma}$ was suggested by Théveniaut et al. (2006) for this part of the curve, based on the $1972 \pm 4 \mathrm{Ma}$ age $\left({ }^{40} \mathrm{Ar} /{ }^{39} \mathrm{Ar}\right.$ in amphibole) obtained for the La Encruzijada granite (Onstott et al. 1984b). A similar age (ca. $1970 \mathrm{Ma}$ ) was also suggested based on the Imataca Complex thermal history, disclosed by hornblende, biotite, and feldspar Ar-Ar dating (Onstott et al. 1989).

Finally, the recent -1960 Ma pole (SG in Tab. 1) determined for the acid volcanic rocks from the Surumu Group (Bispo-Santos et al. 2014a) may indicate an extension of the APW Path traced by Théveniaut et al. (2006) for the interval 2070-1970 Ma (Fig. 3). In Fig. 3, the APW Path traced by Nomade et al. (2003) for West Africa, referring

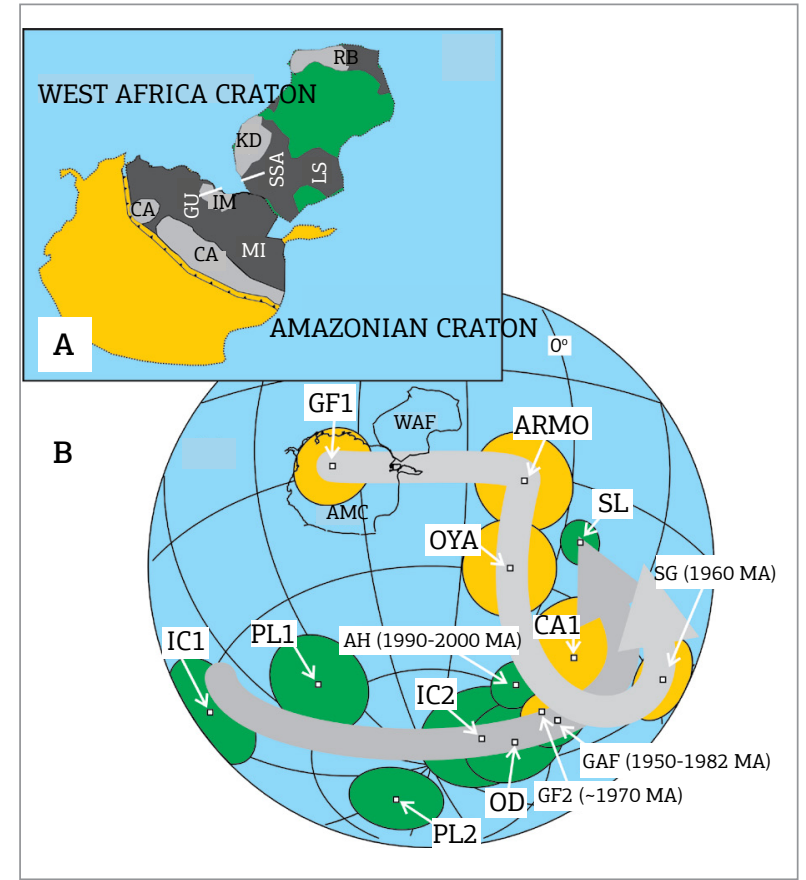

Figure 3. (A) Paleogeographic configuration of the Amazonian Craton and West Africa Craton link at around 2000-1970 Ma ago. Geotectonic provinces: Amazonia (CA - Central Amazonian Province, MI Maroni-Itacaiúnas Province; GU - Guri lineament); West Africa (LS - Leo Shield, KD - Kenemanan Domain, RB - Requibat Shield, SSA - Sassandra lineament). (B) Comparison of the Amazonian and West African 2070-1960 Ma APW Paths. Pole Acronyms: AMC Amazonian Craton (yellow); GF1, ARMO, OYA, GF2 and SG poles (Tab. 1); WAF - West Africa Craton (green); IC1 -Ivory Coast Granites (Nomade et al. 2003); PL1 - Abouasi Amphibolites (Piper \& Lomax 1973); PL2 - Abouasi Dolerites (Piper \& Lomax 1973); OD - Liberia Granites (Onsttot \& Dorbor 1987); IC2 Ferke Granites - Ivory Coast (Nomade et al. 2003); GAF - Aftout Granites (Nomade et al. 2003); AH - Harper Amphibolite - Liberia (Onsttot et al. 1984a); SL - Aftout Gabbros - Algeria (Nomade et al. 2003). West Africa Craton and their corresponding paleomagnetic poles were rotated using the Euler pole at $43.3^{\circ} \mathrm{N} ; 330.5^{\circ} \mathrm{E}$ (rotation angle of $-71.5^{\circ}$ ). Modified after Bispo-Santos et al. (2014a). 
to the time interval $2080-1940 \mathrm{Ma}$, is also shown, after rotation of West Africa and corresponding paleomagnetic poles using an Euler pole located at $43.3^{\circ} \mathrm{N} ; 330.5^{\circ} \mathrm{E}$ (rotation angle of $\left.-71.5^{\circ}\right)$. The proto-Amazonian/West-African paleogeography (Fig. 3) is similar to that proposed by Onstott \& Hargraves (1981), in which the Guri (Guiana Shield) and Sassandra (West Africa) shear zones were part of the same tectonic lineament. Despite the poor quality of the poles applied to trace the West Africa Craton's APW Path (Nomade et al. 2003), the two paths are clearly different for ages older than $2000 \mathrm{Ma}$, and seem to joint at younger ages $(1980-1960 \mathrm{Ma})$, attesting the validity of the formation of this supercraton at about $1980-2000 \mathrm{Ma}$ (Bispo-Santos et al. 2014a) (Fig. 3).

According to Bleeker (2003), during Archean to early Proterozoic transition, there would have been a favorable scenario to the presence of many independent 'supercratons'. Between 2500 and $2000 \mathrm{Ma}$, a diachronic fragmentation would have occurred in the larger supercratons generating around 35 independent cratons, which later on amalgamated into larger continental blocks (e.g. Laurentia) that ultimately formed the Columbia Paleo-Mesoproterozoic supercontinent (Bleeker 2003).

Based on the available paleomagnetic and geologic-geochronological data, we can attempt to reconstruct a proto-Amazonian Craton and its relation with other cratonic blocks at ca. $2000 \mathrm{Ma}$. In general, the paleomagnetic poles from the Amazonian Craton are compared with those from Laurentia and Baltica aiming supercontinental reconstructions. As already stressed, at times prior to Columbia formation, however, any reconstruction must be considered very speculative, since the major cratonic masses that would be assembled in Columbia were still not completely formed. For example, most of Laurentia was only assembled at ca. $1850 \mathrm{Ma}$, after the following collisions: Archean Slave and Rae blocks at 1970 Ma; the Slave/Rae and Hearne blocks at $1920 \mathrm{Ma}$; and this block with the Superior Craton at 1850 $\mathrm{Ma}$ (Mitchell et al. 2014). Following well-dated paleomagnetic poles from Slave and Superior cratons in the interval between $2200 \mathrm{Ma}$ and $2000 \mathrm{Ma}$, Mitchell et al. (2014) demonstrate that these blocks were separated by a very large ocean (Manikewan Ocean) at ca. $2000 \mathrm{Ma}$ (see Fig. 7 in Mitchell et al. 2014). In their reconstruction, the Slave block was rotated $-79^{\circ}$ around an Euler pole at $52^{\circ} \mathrm{N}, 356^{\circ} \mathrm{E}$ relative to the Superior block. Using this reconstruction, we propose a possible paleogeography at $2000 \mathrm{Ma}$ (Fig. 4) that tentatively includes other two cratonic blocks of Laurentia (Rae and Hearne), and also parts of Baltica, Amazonia, and West Africa, partly based on paleomagnetic poles as further described. The relative paleogeographic positions of Slave and Superior cratons (Mitchell et al. 2014) are constrained using the $1998 \mathrm{Ma}$ pole determined for the Minto dykes (pole at $30^{\circ} \mathrm{N}, 183^{\circ} \mathrm{E}, \mathrm{A}_{95}=13^{\circ}$ ) from the Superior Craton. The Rae and Hearne blocks were positioned between these cratonic blocks.

At that time, Central Amazonia had already been assembled with the collision of Archean blocks along the 22502050 Ma Maroni-Itacaiúnas mobile belt (MIMB, Cordani $\&$ Teixeira 2007). Since other Archean blocks collided with Central Amazonia along the MIMB during and after its assembly, it is very likely that the craton at such time was a larger landmass. Based mainly on geological/geochronological evidence, Johansson (2009) proposed the SAMBA model for Columbia, in which West Africa and Sarmatia/ Volgo-Uralia may be the components of this larger cratonic block. As previously discussed, West Africa was linked to the Guiana Shield at least since 1970-2000 Ma in a position

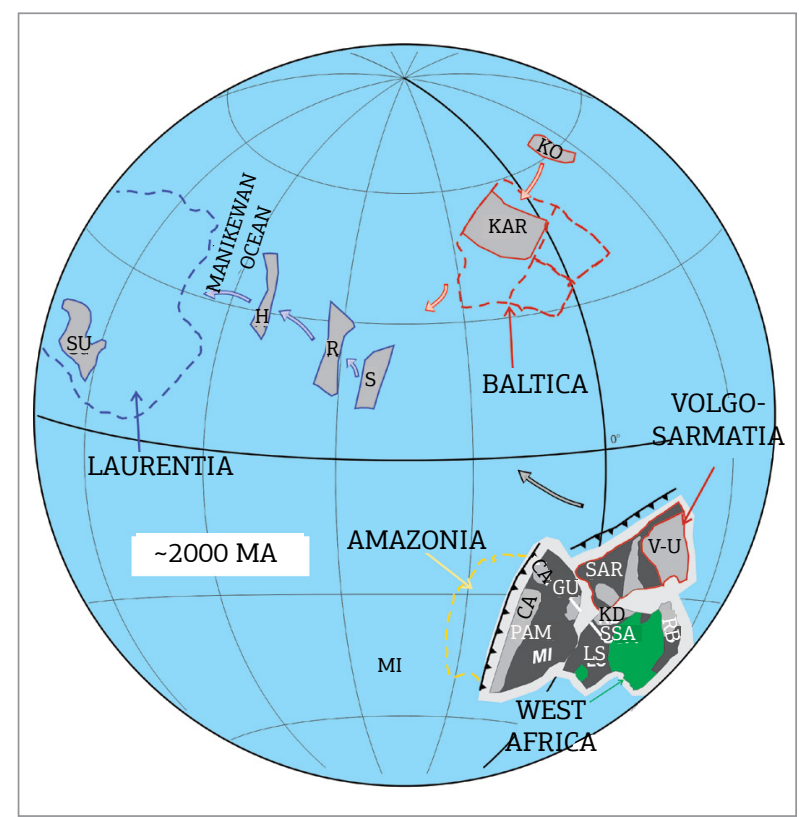

Figure 4. Reconstruction at 2000 Ma partially based on paleomagnetic data. Proto-Amazonia (pAM) was constrained using the OYA pole (Tab. 1). Superior Craton $(\mathrm{Su})$ is constrained using the Minto dykes pole (Buchan et al. 1998, Evans \& Halls 2010). Superior $(\mathrm{Su})$ and Slave $(\mathrm{S})$ relative positions are the same proposed by Mitchell et al. (2014) following paleomagnetic data. Karelia (Kar) is constrained by the 1984 Ma Pudozhgora intrusion pole (Lubnina et al. 2016), and Kola (Ko) Craton is tentatively positioned close to Karelia. In this scenario, it is suggested that proto-Amazonia, West Africa, Volgo-Uralia (V-U), and Sarmatia (SAR) formed a single cratonic mass. The curved arrows indicate the possible later drifts of each cratonic block. CA - Central Amazonian Province; MI Maroni-Itacaiúnas Province; GU - Guri lineament; LS Leo Shield; KD - Kenemanan Domain; RB - Requibat Shield; SSA - Sassandra lineament. 
where the Guri (in Guiana Shield) and Sassandra (in West Africa) lineaments were aligned (Onstott \& Hargraves 1981, Nomade et al. 2003, Bispo-Santos et al. 2014a).

At $2000 \mathrm{Ma}$ ago, Baltica was not yet formed either (see Bogdanova et al. 2001, 2013). Collision between Sarmatia and Volgo-Uralia (from South and East of Baltica Shield, respectively) occurred between 2100 and $2000 \mathrm{Ma}$, forming the Volgo-Sarmatia block. Therefore, based on such arguments, we propose herein that a large landmass was already formed at $2000 \mathrm{Ma}$ composed by Volgo-Uralia, Sarmatia, Central Amazonia, and West Africa agglutinated along Paleoproterozoic mobile belts developed up to $2000 \mathrm{Ma}$. The position of this landmass is constrained by the OYA pole (Tab. 1) obtained for the Oyapok granitoids with an $\mathrm{Ar}-\mathrm{Ar}$ (amphibole) age of $2020 \pm 4 \mathrm{Ma}$. At that time, active subduction zones were in progress at the Northern and Western margins of Volgo-Sarmatia and Central Amazonia, respectively (Fig. 4).

Karelia and Kola Archaean areas from north-northwestern part of the Baltica Shield were far from VolgoUralia and Sarmatia blocks at $2000 \mathrm{Ma}$ (Bogdanova et al. 2013). In Fig. 4, the Karelia position was constrained by the 1984 Ma Pudozhgora Intrusion pole (Lubnina et al. 2016), and Kola Craton is tentatively positioned close to Karelia. According to Daly et al. (2006), after the formation of the Archean Kernoland supercontinent (Pesonen et al. 2003), a Wilson cycle was developed between Kola and Karelia after the break-up of this supercontinent at ca. $2500 \mathrm{Ma}$. This was followed by the formation of an ocean and its later closure, culminating with the docking of Kola and Karelia along the Lapland-Kola orogen at ca. $1900 \mathrm{Ma}$.

Between 1830 and $1800 \mathrm{Ma}$, an oblique collision took place between Volgo-Sarmatia with Fennoscandian terrains (Kola-Karelia) along the NW part of Sarmatia (Bogdanova et al. 2013). After this oblique collision, Volgo/Sarmatia (together with Central Amazonia and West Africa in our model) performed a counterclockwise rotation that activated older strike-slip faults (Bogdanova et al. 2013). These fault systems accommodated mafic dyke swarms with ages between 1790 and $1750 \mathrm{Ma}$ in the Ukrainian Shield (northwestern Sarmatia). At the same time (1790-1780 Ma), profuse mafic intrusions occurred as dykes and sills at the Guiana Shield, spreading over Venezuela, French Guiana and northern Brazil (Reis et al. 2013, Bispo-Santos et al. 2014b). After Columbia formation at $1780 \mathrm{Ma}$ (Bispo-Santos $e t$ al. 2014b), minor internal rotations happened associated with $1750 \mathrm{Ma}$ mafic dykes at the Ukrainian Shield (Bogdanova et al. 2013).

\section{THE AMAZONIAN CRATON IN THE COLUMBIA SUPERCONTINENT}

According to Rogers \& Santosh (2009), the Columbia supercontinent mostly assembled at about 1900-1850 Ma, as suggested by geologic correlations, age constraints, and other lines of evidence, like significant atmospheric changes (Bleeker 2003). However, different paleogeographic scenarios of Columbia were proposed, mainly due to scarcity of high-quality paleomagnetic poles (e.g. Meert 2002, Zhao et al. 2002, 2003, 2004, Pesonen et al. 2003, 2012, Hou et al. 2008a, 2008b, Johansson 2009, Rogers \& Santosh 2009, Wingate et al. 2009, Yakubchuk 2010, Evans \& Mitchell 2011, Zhang et al. 2012, Pisarevsky et al. 2014; among others).

In recent years, several Paleo-to Mesoproterozoic geological units from the Amazonian Craton were investigated to establish its role in the Columbia Supercontinent. The first paleomagnetic study was conducted on the $1780 \mathrm{Ma}$ felsic volcanic rocks of the Colíder Suite (Bispo-Santos et al. 2008), now called Colíder Group, located in northern Mato Grosso State, Brazil-Central (or Guaporé) Shield (Lacerda Filho et al. 2004). Based on these results, the paleogeographic scenario visualized for Columbia at $1780 \mathrm{Ma}$ has Laurentia, Baltica, North China and proto-Amazonia aligned in a north to south continental mass forming the core of Columbia Supercontinent (Bispo-Santos et al. 2008) (Fig. 5A). Geological evidence favor the hypothesis that proto-Amazonia and North China were laterally disposed at 1780 Ma ago. Subduction-related processes were developed in the western margin of the East Block of North China Craton and along the southwestern proto-Amazonian Craton. This process culminated with the docking of the West Block from North China Craton, along the Trans-North China Belt at ca. $1850 \mathrm{Ma}$ ago, establishing the final configuration of North China Craton. Meanwhile, Ventuari-Tapajós accretion was in progress along the southwestern Amazonian Craton. Cordani et al. (2009) restated this interpretation again in a broad discussion on the evolution of the Amazonian Craton and its role in the formation of supercontinents.

Subsequently, paleomagnetic studies on rocks from the Nova Guarita mafic dyke swarm (Bispo-Santos et al. 2012) and Indiavaí Intrusive (D'Agrella-Filho et al. 2012), also located in Mato Grosso State (Brazil-Central Shield), corroborated the paleogeographic model proposed by Bispo-Santos et al. (2008). ${ }^{40} \mathrm{Ar} /{ }^{39} \mathrm{Ar}$ geochronological dating on biotite and plagioclase minerals separated from four Nova Guarita dykes yielded plateau ages between $1407 \pm 8 \mathrm{Ma}$ and $1430 \pm 8 \mathrm{Ma}$. An 
average of $1418 \pm 3 \mathrm{Ma}$ was calculated, which was interpreted as the intrusion age of the dykes (Bispo-Santos et al. 2012). A positive baked contact test obtained for one of the dykes that cut the Paleoproterozoic Matupá granite demonstrates the primary nature of the characteristic remanent magnetization (ChRM) isolated for these rocks (see Bispo-Santos et al. 2012). The Indiavaí Intrusive belongs to a set of mafic bodies collectively known as Figueira Branca Intrusive Suite (Bettencourt $e t$ al. 2010). U-Pb dating performed on zircons extracted from Indiavaí and Figueira Branca Intrusives provided ages of $1425 \pm 8 \mathrm{Ma}$ and $1415 \pm 6 \mathrm{Ma}$, respectively, which were interpreted as the crystallization times of these bodies (Teixeira et al. 2011). Although a baked contact test performed for the Indiavaí Intrusive resulted inconclusive (D’Agrella-Filho et al. 2012), similar radiometric
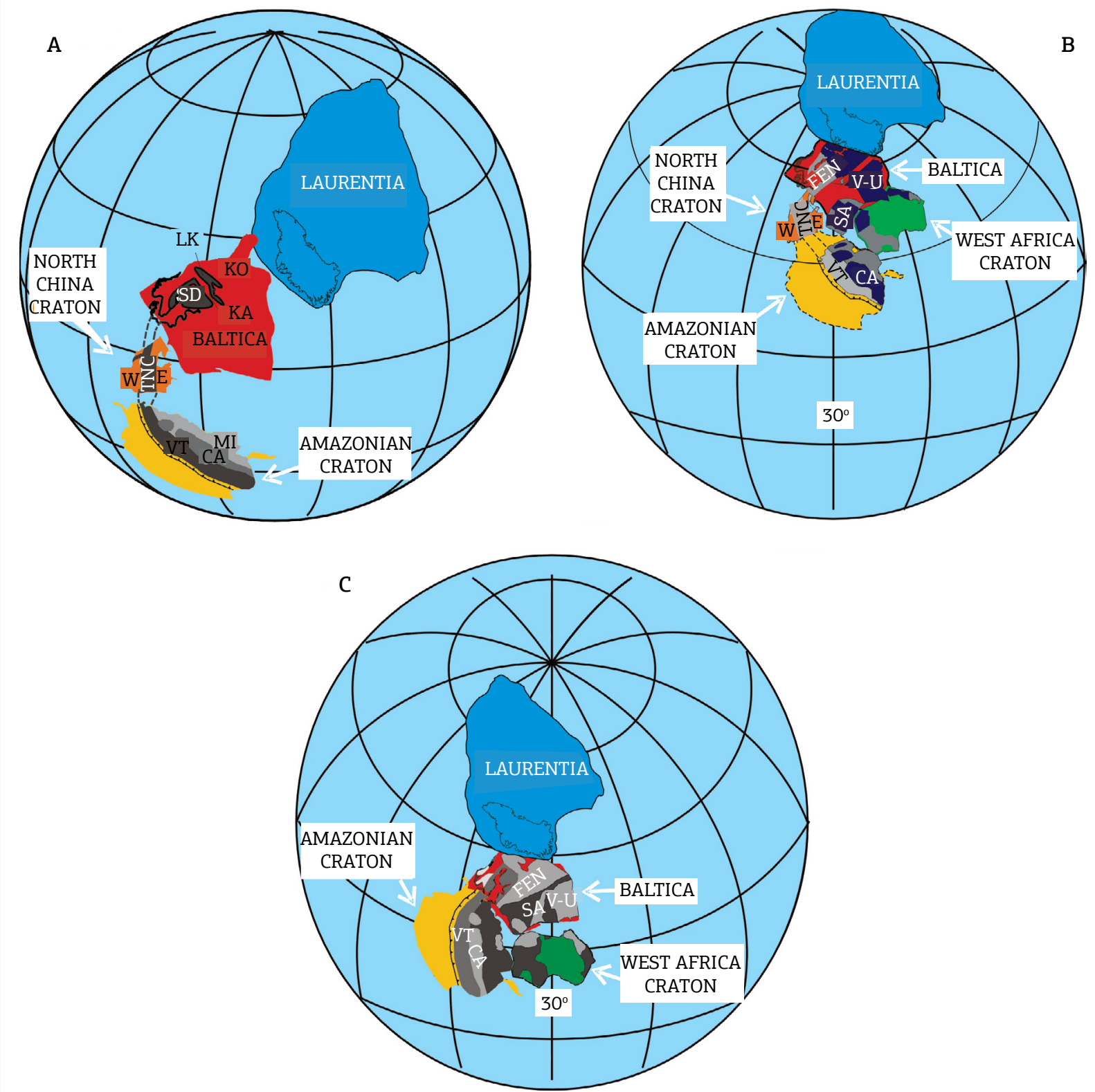

Figure 5. Paleogeographic reconstructions at $1790 \mathrm{Ma}$ as proposed by: (A) Bispo-Santos et al. (2008), (B) D'AgrellaFilho et al. (2012), and (C) Bispo-Santos et al. (2014b). Baltica (FEN - Fennoscandia; V-U - Volgo-Uralia; SA - Sarmatia; KO - Kola; KA - Karelia; LK - Lapland-Kola; SD - Svecofennian Domain); Amazonia (CA - Central Amazonian Province; MI - Maroni-Itacaiúnas Province; VT - Ventuari-Tapajós Province); and North China Craton (W -West Block; E - East Block; TNC -Trans-North China belt). 
ages and ChRM directions obtained for Indiavaí and Nova Guarita rocks strongly suggest they both preserved thermoremanent magnetizations, acquired during rock intrusions at ca. $1415-1425 \mathrm{Ma}$.

These Mesoproterozoic poles (Tab. 1) have important implications regarding the significance of the Nova Brasilândia Belt (NBB - Fig. 2). Based on geophysical data and structural inferences, Tohver et al. (2004a) interpreted NBB as a suture zone between the Paraguá Terrain (which, in their view, would also include Mato Grosso area, to the south of NBB) and the proto-Amazonian Craton. This model follows primarily the strong contrast between the monocyclic history of NBB, composed by high pressure and temperature granulites (1090-1060 Ma), and the polycyclic history of the basement rocks to the north, with evidence of sinistral strike-slip deformation dated at $1190-1130 \mathrm{Ma}$ (the Ji-Paraná shear zone). Other evidence presented by Tohver $e t$ al. (2004a) refer to the strong magnetic lineament disclosed by aeromagnetic data, which suggests the continuity of NBB to the east under Serra dos Parecis sedimentary cover. This interpretation, however, contrasts with that of other authors, who suggest that the NBB resulted from intracratonic reactivations during the evolution of Sunsás Belt situated on the southwestern tip of the Amazonian Craton (e.g. Cordani \& Teixeira 2007). The similarity of Nova Guarita and Indiavaí poles obtained for geological units situated on opposite sides of NBB supports this latter interpretation (D'Agrella-Filho et al. 2012). Nevertheless, the position of these poles, almost perpendicular to NBB, permitted that transcurrent movements along this belt occurred, which might have originated the Ji-Paraná sinistral shear zone previously described.

With regard to the paleogeography of Columbia, the new paleomagnetic data disclosed for Colíder Group $(1780 \mathrm{Ma})$, Nova Guarita dykes (1419 Ma), and Indiavaí Intrusive $(1416 \mathrm{Ma})$ corroborate the model initially proposed by Bispo-Santos et al. (2008) (Fig. 5a). In such model, Laurentia, Baltica, North China Craton and proto-Amazonian Craton were laterally disposed, forming the core of Columbia Supercontinent (D'Agrella-Filho et al. 2012) (Fig. 5b). West Africa Craton can be included in the model assuming it was linked to the proto-Amazonian Craton (Onstott \& Hargraves 1981, Nomade et al. 2003, Johansson 2009, Evans \& Mitchell 2011, BispoSantos et al. 2014a). However, some adjustments should be done to accommodate geological information taking into account the uncertainties of the available paleomagnetic poles. Thus, in the Columbia Supercontinent proposed by D'Agrella-Filho et al. (2012), Sarmatia was rotated $43^{\circ}$ counter-clockwise (Fig. 5b), as suggested by Elming et al. (2010), based on paleomagnetic and geological evidence. D'Agrella-Filho et al. (2012) also speculated on the presence of a triple junction between Fennoscandia, Sarmatia, North China, and Amazonia (see Fig. 13 in D'Agrella-Filho et al. 2012).

According to such model, soon after the formation of Columbia core, around $1850 \mathrm{Ma}$ ago, dextral strike-slip movements occurred between North China and Fennoscandia and sinistral ones between North China and Amazonia/Sarmatia unit. Rupture of North China would be consistent with the profusion of 1780-1790 Ma mafic dykes and sills exposed in northern Brazil, Venezuela and Guyana, known as the Avanavero Large Igneous Province (LIP - Gibbs 1987, Santos et al. 2003, Reis et al. 2013), with the felsic and mafic dykes from Småland province in southwestern Baltica (Pisarevsky \& Bylund 2010); the 1770-1780 Ma gabbros and dolerites belonging to the Ropruchey sills in eastern Fennoscandia (Fedotova et al. 1999); and the profusion of similar in age dykes spread over North China (Kusky et al. 2007).

Although Paleo to Mesoproterozoic paleomagnetic data of the southeastern Amazonian Craton (Brazil-Central Shield) support a model in which Laurentia, Baltica, North China Craton, and Amazonian/West Africa Cratons were laterally displayed, thus forming the core of Columbia Supercontinent (D'Agrella-Filho et al. 2012), in most Columbia models, the Amazonian Craton appears directly linked to Baltica, in a reconstruction called SAMBA connection formally proposed by Johansson (2009).

Recently, a paleomagnetic study was conducted on mafic sills and dykes belonging to the Avanavero LIP, located in northern Roraima State (Guiana Shield). These rocks are very well-dated by the U-Pb method (seven determinations on zircon and baddeleyite), whose $1788 \pm 2 \mathrm{Ma}$ mean age is interpreted as the rock crystallization age (Reis et al. 2013, Bispo-Santos et al. 2014b). A paleomagnetic pole graded with quality factor (Q) five (Tab. 1) was found for the Avanavero event. Studies of magnetic mineralogy, petrography and a positive baked contact test point out to a primary nature of ChRM directions isolated for these rocks (BispoSantos et al. 2014b).

The Avanavero pole agrees with coeval poles from Baltica and Laurentia, if SAMBA reconstruction is considered, based on geological and geochronological data (Bispo-Santos et al. 2014b) (Fig. 5C). Furthermore, we can envisage the agglutination of these masses, starting from the reconstruction at $2000 \mathrm{Ma}$ ago in Fig. 4, in which the landmass formed by proto-Amazonia, West Africa and Volgo-Sarmatia obliquely collided with Fennoscandia, and other cratonic masses that formed Laurentia.

However, the Avanavero pole is very different from the Colider pole, and therefore does not support Columbia's models suggested by Bispo-Santos et al. (2008) (Fig. 5A), 
based on the Colíder pole, and D'Agrella-Filho et al. (2012) (Fig. 5B), according to Paleo- to Mesoproterozoic poles. Two hypotheses could be raised to explain this difference:

1. although the rocks have similar ages, their magnetizations were acquired at different times;

2. their magnetizations were obtained during rock crystallization at 1780 to $1790 \mathrm{Ma}$, however, a relative movement occurred between the two areas after magnetization was acquired by rocks.

If we accept the first hypothesis, four facts lead us to assume that SAMBA model (Johansson 2009) should prevail over those proposed by Bispo-Santos et al. (2008) and D'Agrella-Filho et al. (2012). Therefore:

1. the Avanavero pole was obtained for anorogenic rocks emplaced in an intracratonic environment (Guiana Shield), whose Hadean-Archean to Paleoproterozoic basement was only partially affected in its southern part by the 1200 Ma K'Mudku event (Cordani et al. 2010);

2. the magnetic and petrographic evidence added to a positive baked contact test obtained for Avanavero rocks suggest that their ChRM directions most likely result from thermo-remanent magnetizations acquired during rock cooling at about $1789 \mathrm{Ma}$ ago;

3. no stability tests were performed for the Colíder rocks; Colíder pole was obtained for 1780-1790 Ma felsic rocks from the southern part of Amazonian Craton, where NW-SE magmatic arcs were being formed along the Jauru Terrain up to the final collision of Paraguá Terrain at 1320 $\mathrm{Ma}$ (Bettencourt et al. 2010). This makes easier to assume that the Colíder pole represents a secondary magnetization;

4. the presently available $1530 \mathrm{Ma}$ paleomagnetic data for Amazonia, Baltica and Laurentia are also consistent with the SAMBA model (Pesonen et al. 2012).

On the other hand, if both magnetic records represent the primary magnetization, a possible explanation for the difference in the paleomagnetic poles from Colíder and Avanavero igneous units could be that after their emplacement at $1780 \mathrm{Ma}$ ago, approximately NW dextral strike-slip motions occurred between the northern part of the craton where the Avanavero sills and dykes crop out, and the southern of the craton, in which the acid volcanic rocks from Colíder Group are housed in (Bispo-Santos et al. 2014b).

Another interesting fact emerges when the $-1420 \mathrm{Ma}$ Nova Guarita and Indiavaí poles are compared with coeval poles from Baltica and Laurentia, after their rotation to the SAMBA configuration (see Fig. 12 in Bispo-Santos et al. 2014b). In such case, a difference between these poles is also observed, which is similar to that of the Avanavero-Colíder poles and once more point to $\mathrm{NW}$ dextral movements between the southern part of the Amazonian Craton and the northernmost portions of the Columbia supercontinent. Therefore, it suggests that if these strike-slip movements are real, they must have occurred after $1420 \mathrm{Ma}$.

In this scenario, the recent recognition of the Trincheira ophiolite in southwestern Amazonian Craton (Rondônia State) suggests that collision of the Paraguá Terrain with the proto-Amazonian Craton along the Alto Guaporé Belt occurred between $\sim 1470$ and $1320 \mathrm{Ma}$ (Bettencourt et al. 2010, Rizzotto \& Hartmann 2012). This collisional event probably originated the NW-SE lineaments (Buiuçu Shear Zone; Almeida et al. 2012) observed to the east of Trincheira ophiolite, where mylonitic rocks were dated at $1466.5 \pm 1.4 \mathrm{Ma}$ (Ar-Ar on muscovite) and $1467.8 \pm 0.8 \mathrm{Ma}$ (Ar-Ar on sericite). These shear zones are interpreted as the result of the Rondonian-San Ignacio orogeny (Cordani et al. 1979, Tassinari et al. 1996, Almeida et al. 2012) that led to the collision of Paraguá Terrain. In face of these facts, Bispo-Santos $e t$ al. (2014b) speculated that if both paleomagnetic poles represent primary $\mathrm{ChRM}$ directions, reactivation of these faults could be, at least partly, responsible for the NW-SE dextral movements implied by the available paleomagnetic data.

Furthermore, later tectonic events affected the Amazonian Craton, which may have produced relative movements between the northern Guiana Shield and the Brazil-Central Shield. We highlight the Late Mesoproterozoic intracratonic displacements associated with the Amazonian Craton/Laurentia collision along the Sunsás-Grenville orogenic belts - e.g. the 1200-950 Ma Aguapeí mobile belt; the ca. 1100 Ma NBB; and NE-SW shear zones associated with ca. $1200 \mathrm{Ma}$ K'Mudku event that affected the southern part of the Avanavero event (Reis et al. 2003, Tohver et al. 2004a, Teixeira et al. 2010, Cordani et al. 2010). ENE-WSW to NE-SW shear zones associated with the Rondônia-San-Ignacio rocks in Rondônia State, which were dated at $1300.1 \pm 1.4 \mathrm{Ma}$ (plateau Ar-Ar age in muscovite), may have been caused by Sunsás orogen activity (Almeida et al. 2012). Also, the polydeformed basement to the north of the NBB is marked by intense shear zones at about 1150 $\mathrm{Ma}$, although mylonitic rocks formed in the tectonic process display a systematic sinistral shear sense in this case (Tohver et al. 2004a).

Pisarevsky et al. (2014) also discussed the Paleoproterozoic (Colíder and Avanavero) and Mesoproterozoic (Nova Guarita and Indiavaí) poles from Amazonia. They contested the explanation presented by Bispo-Santos et al. (2014b) arguing that displacements between the parts of Amazonia are unlikely, as they would disrupt the linearity of the Ventuary-Tapajós province. Alternatively, they propose that Amazonia/West Africa was positioned outboard of the peripheral subduction system comprised by Laurentia and Baltica at $1770 \mathrm{Ma}$ (see Fig. 7 in Pisarevsky et al. 2014). 
Other models of Columbia, however, are possible, for which smaller mismatches of the Mesoproterozoic poles from Amazonia, Baltica and Laurentia are observed (e.g. Zhang et al. 2012, Xu et al. 2014, Pehrsson et al. 2016). Recently, D'Agrella-Filho et al. (2016) presented new paleomagnetic data about the 1440 Ma Salto do Céu mafic sills and sedimentary rocks cut by the sills. Comparison of selected 1460$1400 \mathrm{Ma}$ poles from Baltica and Laurentia with available Mesoproterozoic poles from Amazonia are shown in Fig. 6 for each reconstruction of Columbia proposed by Bispo-Santos et al.

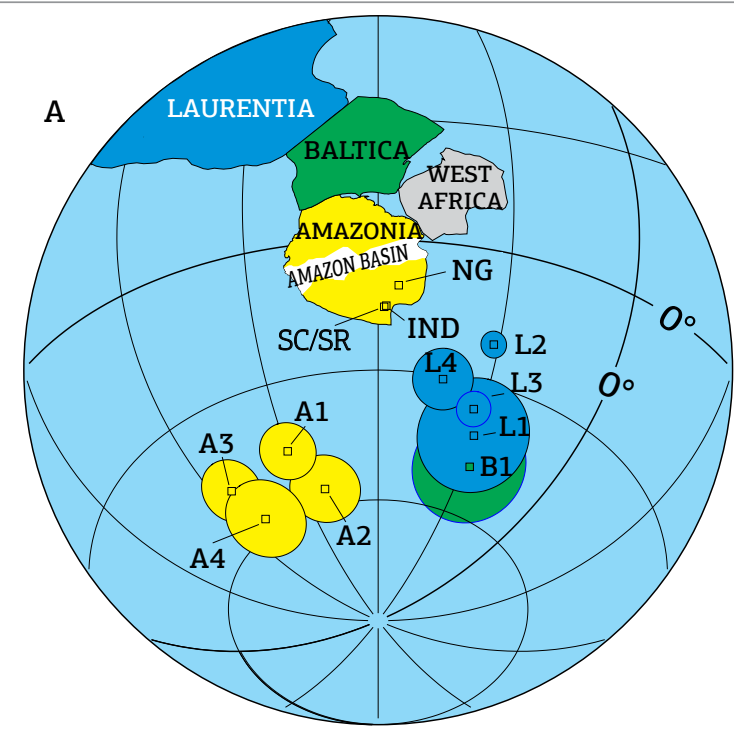

Bispo-Santos et al. (2014b)

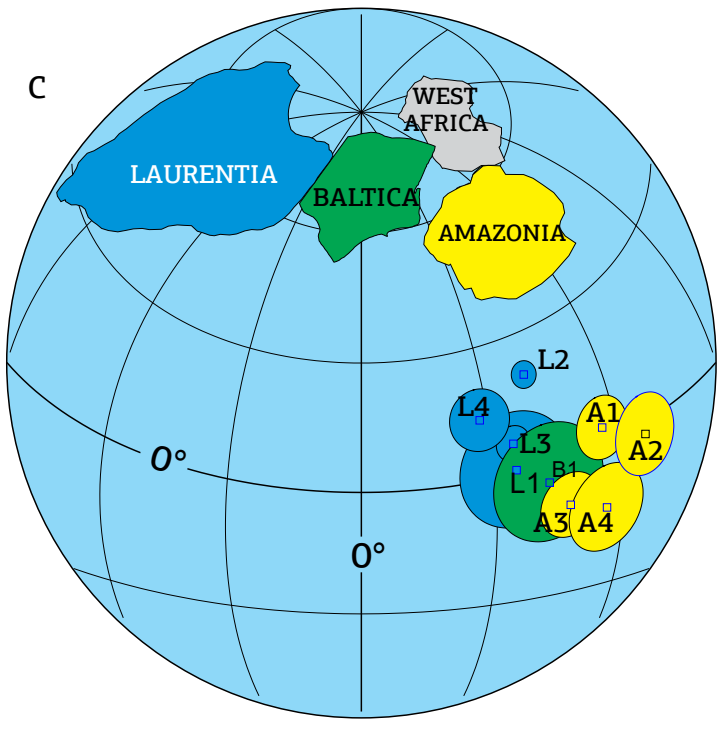

$\mathrm{Xu}$ et al. (2014)

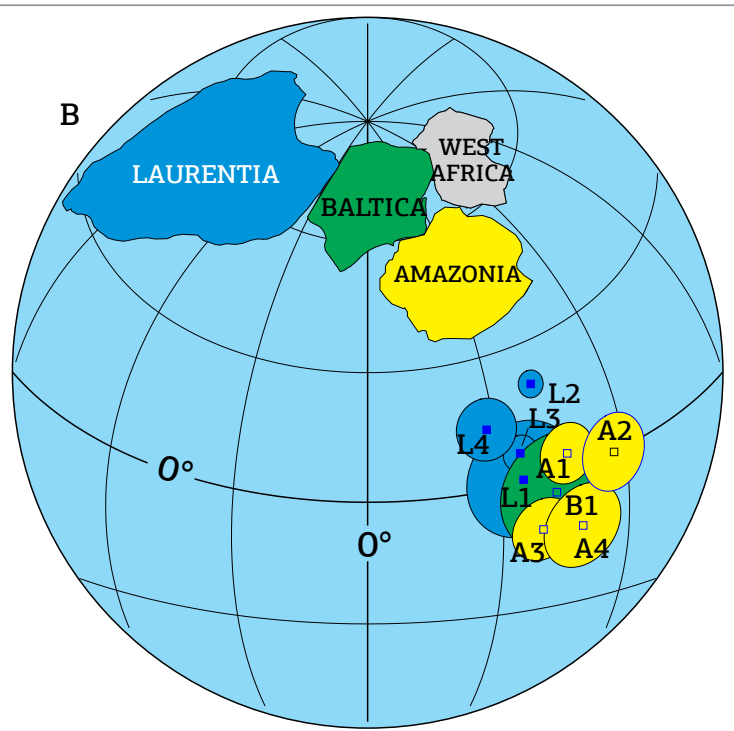

Zhang et al. (2012)

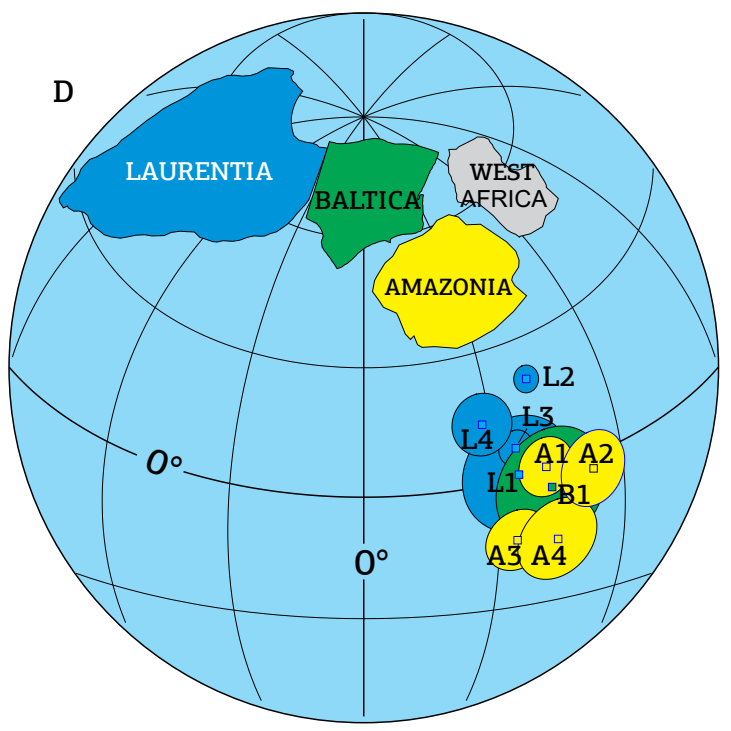

Pehrsson et al. (2016)

Figure 6. Comparison of Mesoproterozoic poles from the Amazonian Craton, Laurentia, and Baltica considering the reconstruction of Columbia proposed by (A) Bispo-Santos et al. (2014b); (B) Zhang et al. (2012); (C) Xu et al. (2014); and (D) Pehrsson et al. (2016) (based on D'Agrella-Filho et al. 2016). Mesoproterozoic paleomagnetic poles, and their confidence circles $\left(\alpha_{95}\right)$ : Amazonia - (A1) Rio Branco Sedimentary rocks; (A2) Salto do Céu sills; (A3) Nova Guarita Dykes; (A4) Indiavaí Intrusive (Tab. 1); Baltica - (B1) 1460 Ma mean pole (Bispo-Santos et al. 2014b); Laurentia - (L1) 1460 Ma mean pole; (L2) McNamara pole (1401 \pm 6 Ma); (L3) Electra Lake Gabbro (1433 $\pm 2 \mathrm{Ma}$ ); (L4) Laramie Anorthosite (1429 $\pm 9 \mathrm{Ma}$ ) (Bispo-Santos et al. 2014b). Paleomagnetic poles are represented in the same color of the respective cratonic blocks. Euler rotation poles used for paleomagnetic poles and cratonic blocks as in D'Agrella-Filho et al. (2016). Geographical positions of Salto do Céu sills (SC), Rio Branco sedimentary rocks (SR), Indiavaí Intrusive (IND) and Nova Guarita Dykes (NG) are shown in (A). 


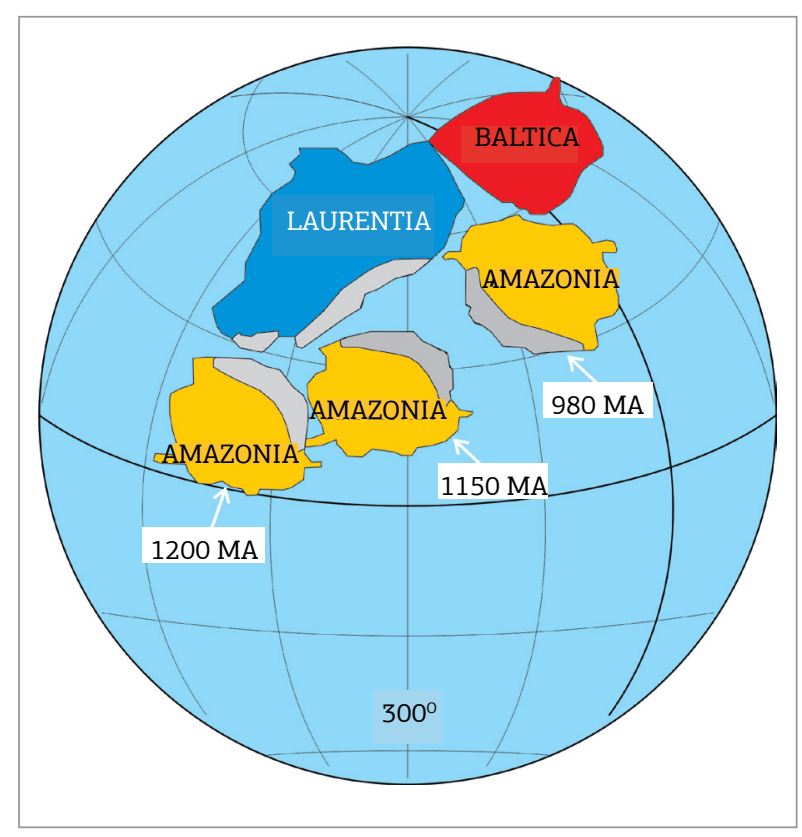

Figure 7. Geodynamical interaction model of the Amazonian Craton and Laurentia between $1200 \mathrm{Ma}$ and $980 \mathrm{Ma}$ (after Elming et al. 2009). Amazonian positions relative to Laurentia (North America in its present position) are shown at $1200 \mathrm{Ma}$ (based on Nova Floresta pole - NF pole in Tab. 1), at $1150 \mathrm{Ma}$ (based on Fortuna Formation pole - FT in Tab. 1), and at $980 \mathrm{Ma}$ (based on Aguapeí sills pole of Elming et al. 2009).

(2014b), Zhang et al. (2012), Xu et al. (2014), and Pehrsson et al. (2016), as seen in Figs. 6a to 6d, respectively. The best cluster of poles is obtained through the reconstruction of Pehrsson et al. (2016), in which Amazonia appears rotated counterclockwise relative to the reconstruction of Bispo-Santos et al. (2014b) (Fig. 6a), and may indicate internal plate rotations inside Columbia. Note this reconstruction is similar to that proposed by Bispo-Santos et al. (2012). Nevertheless, it is clear that new Mesoproterozoic poles from the Amazonian Craton, mainly from the northern Guiana Shield, are required before we decide the best model proposed for Columbia.

\section{THE AMAZONIAN CRATON: RODÍNIA'S PRODIGAL SON}

The Amazonian Craton is one of the largest and most complete fragments of Rodínia's rupture, and possibly the only one of its descendants to take part in the Western Gondwana. Trying to increase our understanding about the paleogeographic evolution and dynamic interaction between Laurentia and the Amazonian Craton, other paleomagnetic investigations were carried out. Sedimentary rocks belonging to the Aguapeí Group and mafic sills cutting these rocks became the targets of paleomagnetic studies performed in western Mato Grosso State by D'Agrella-Filho et al. (2008) and Elming et al. (2009), respectively. For the study of the Aguapeí Group, redbeds described as belonging to Fortuna Formation (the basal unit) and gray pelitic sedimentary rocks of Vale da Promissão Formation (intermediate unit) were collected close to Vila Bela (next to the Brazil-Bolivia boundary) and Rio Branco (on the other side of the basin) cities, respectively. $\mathrm{U}-\mathrm{Pb}$ detrital zircon ages ranging from $1453 \pm 10 \mathrm{Ma}$ to $1165 \pm 27 \mathrm{Ma}(\mathrm{n}=89)$ established the maximum deposition age for the Fortuna Formation at $1165 \mathrm{Ma}$ (Santos et al. 2001, Leite \& Saes 2003).

The paleomagnetic study of Fortuna Formation rocks enabled isolating ChRM directions carried by diagenetic hematite (D'Agrella-Filho et al. 2008). An age of $1149 \pm 7 \mathrm{Ma}$ was assigned to Fortuna Formation pole (Tab. 1), based on $\mathrm{U}-\mathrm{Pb}$ (SHRIMP) dating of authigenic xenotime rims on detrital zircon grains. This paleomagnetic pole, when compared with coeval poles belonging to Laurentia (D'AgrellaFilho et al. 2008), seems to support the model proposed by Tohver et al. (2004b), which suggests an oblique collision followed by a strike-slip movement between the Amazonian Craton and Laurentia (Fig. 7). A similar model was used to explain the Colombian-Oaxaquian peri-Amazonian fringing arc system (Putumayo orogeny) outboard of Amazonia that evolved during the Amazonia transcurrent movement up to its final collision with Baltica in late Mesoproterozoic times (Ibanez-Mejia et al. 2011).

On the other hand, the gray pelitic sedimentary rocks collected near Rio Branco region disclosed reversed ChRM directions, in general, carried by magnetite. The absence of direct geochronological dating of these rocks did not permit to establish the age of the corresponding paleomagnetic pole (D’Agrella-Filho et al. 2008).

Paleomagnetic and geochronological studies were also performed on Aguapeí mafic sills (Rio Branco region, Mato Grosso State) cutting the pelitic sedimentary rocks (Elming et al. 2009). These sills and dykes belong to Salto do Céu Intrusive Suíte (Araújo-Ruiz et al. 2007), but Elming et al. called them Aguapeí (hereafter we will use the Salto do Céu original name, see also D'Agrella-Filho et al. 2016). In summary, the laboratorial treatments (alternating field - AF and thermal demagnetization) revealed southwest (northeast) directions with downward (upward) inclinations for ten sites $\left(\mathrm{Dm}=11.3^{\circ} ; \mathrm{Im}=-57.9^{\circ} ; \alpha_{95}=8.1^{\circ}, \mathrm{K}=37\right)$, which yielded a paleomagnetic pole (Salto do Céu pole) located at $64.3^{\circ} \mathrm{S} ; 271.0^{\circ} \mathrm{E}\left(\mathrm{A}_{95}=9.2^{\circ}\right)$. An age of $981 \pm 2 \mathrm{Ma}$ was determined for one of the sills by ${ }^{40} \mathrm{Ar}-{ }^{39} \mathrm{Ar}$ (whole rock). Assigning this age to Salto do Céu pole, Elming et al. (2009) proposed a paleogeographic reconstruction, showing the 
Amazonian Craton position relative to Laurentia at $\sim 980$ Ma ago (Elming et al. 2009), which follows the transcurrent model firstly proposed by Tohver et al. (2004a, 2004b) and later supported by D’Agrella-Filho et al. (2008), as in Fig. 7.

Two facts should be highlighted in this reconstruction:

1. Laurentia paleomagnetic poles in the age range between 1000 and 900 Ma come from high-grade metamorphic rocks related to the Grenville event. The ages of these poles were obtained, in general, from ${ }^{40} \mathrm{Ar}-{ }^{39} \mathrm{Ar}$ single-mineral dating (amphibole, biotite, and plagioclase), and it is not always easy to correlate radiometric and rock magnetization ages;

2. The paleogeographic reconstruction proposed by Elming et al. (2009) was based on the transcurrent model of Tohver et al. (2004a, 2004b), which shows that the Amazonian Craton at $980 \mathrm{Ma}$ (based on Salto do Céu pole) rotated approximately $180^{\circ}$ to its position at $1200 \mathrm{Ma}$ (based on Nova Floresta pole of Tohver et al. 2002), during the $-3000 \mathrm{~km}$ sinistral motion along the Grenvillian margin (see Fig. 7). Although such large rotations may occur, the final position of the Amazonian Craton to Laurentia is very different from that normally admitted in Rodínia reconstructions (see Weil et al. 1998, D’Agrella-Filho et al. 1998, Li et al. 2008, Ibanez-Mejia et al. 2011).

A new U-Pb dating on baddeleyite extracted from Salto do Céu sill (Rio Branco region) has recently yielded an upper intercept age of $1439 \pm 4 \mathrm{Ma}$ on the U-Pb concordia diagram, which is interpreted as the crystallization age of the rock (Teixeira et al. 2016). This age contrasts with the previous 981 $\pm 2 \mathrm{Ma} \mathrm{Ar}$-Ar age and enables an alternative interpretation for Salto do Céu sills pole. The new baddeleyite age correlates well with the U-Pb zircon ones of $1471 \pm 8 \mathrm{Ma}$ and $1427 \pm$ $10 \mathrm{Ma}$, respectively, for a gabbro and a granophyre belonging to Rio Branco mafic-felsic Suite (Geraldes et al. 2001), suggesting that Salto do Céu sills belong to the same event.

Geraldes et al. (2014) presented a provenance study on 100 detrital zircons extracted from Rio Branco sedimentary rocks at Salto do Céu region (their AG-1 sample). The U-Pb determinations showed four age populations for these zircons: $1544,1655,1812$, and $2515 \mathrm{Ma}$. The younger population (age peak of $1544 \mathrm{Ma}$ ) may represent detrital zircons derived from the Cachoeirinha event rocks (from 1580 to $1520 \mathrm{Ma}$ ), and indicate the maximum depositional age for that unit (Geraldes et al. 2014). The identification by Ruiz (2005) of xenoliths from these sedimentary rocks inside the Rio Branco igneous rocks (age of $1427 \pm 10 \mathrm{Ma}$ ) also suggests they are older than those near Vila Bela, whose detrital zircon ages indicate a maximum of $1126 \mathrm{Ma}$ for them (Santos et al. 2001, Leite \& Saes 2003). These results demonstrate that the pelitic sedimentary rocks previously interpreted as the intermediate unit of Aguapeí Group must in fact be correlated with other sedimentary rocks, probably the Dardanelos Group to the north of the Phanerozoic Serra dos Parecis sedimentary cover (Lacerda-Filho et al. 2004). In such case, Salto do Céu sills pole (now dated at $1439 \mathrm{Ma}$ ) cannot be used to represent the Amazonian Craton position in the context of Rodínia, and the paleogeographic interpretation made by Elming et al. (2009) using this pole should be revised.

Trying to prove the primary nature of the magnetization carried by the sills, recently, D'Agrella-Filho et al. (2016) sampled eight new paleomagnetic sites from Salto do Céu sills and samples from five profiles of sedimentary rocks close to the contact with the sills for baked contact tests. The results obtained for the sills and sedimentary rocks are similar to those from Elming et al. (2009) and D'AgrellaFilho et al. (2008), respectively, in the previous studies of these rocks. More statistically robust paleomagnetic poles were calculated for the sedimentary rocks (A1 pole in Tab. 1 now called Rio Branco sedimentary rocks pole) and for the sills (A2 pole in Tab. 1) that supersede older poles. Although the baked contact test was inconclusive, because no different magnetization direction was disclosed for sedimentary rocks far from the sills, ages around $1440 \mathrm{Ma}$ for these paleomagnetic poles are supported by the Nova Guarita (1419 Ma) and Indiavaí (1416 Ma) poles. Fig. 6A shows the poles for the sedimentary rocks from Rio Branco area (pole A1), Salto do Céu sills (pole A2), the 1419 Ma Nova Guarita dyke swarm (pole A3), and the 1416 Ma Indiavaí Intrusive (pole A4). All these poles plot close together suggesting similar ages for all of them.

Recently, Evans (2013) (followed by Johansson 2014) proposed an alternate scenario for the dynamic interaction between Laurentia, Baltica, and the Amazonian Craton (see Fig. 3 in Evans, 2013) that totally contrasts with that proposed by Tohver et al. (2004b), D'Agrella-Filho et al. (2008) and Elming et al. (2009). Due to the polarity ambiguity, Evans (2013) argues that a different model may be proposed if we use the Amazonian Craton's anti-poles. In the Evans' model, after SAMBA rupture in Columbia, Baltica and Amazonian Craton performed clockwise rotations, and docked again with Laurentia, the Amazonian Craton faced to Grenville Belt in the present Labrador region. Partially based on paleomagnetic data, Fig. 8 shows a possible dynamic scenario for Columbia rupture, clockwise rotation of Amazonia and Baltica, and posterior collision of these blocks with Laurentia. Paleomagnetic data suggest that Laurentia and Baltica behaved as a unique block at least up to $1265 \mathrm{Ma}$ (Salminen \& Pesonen 2007). Fig. 8B provides the configuration of SAMBA connection (after Bispo-Santos 


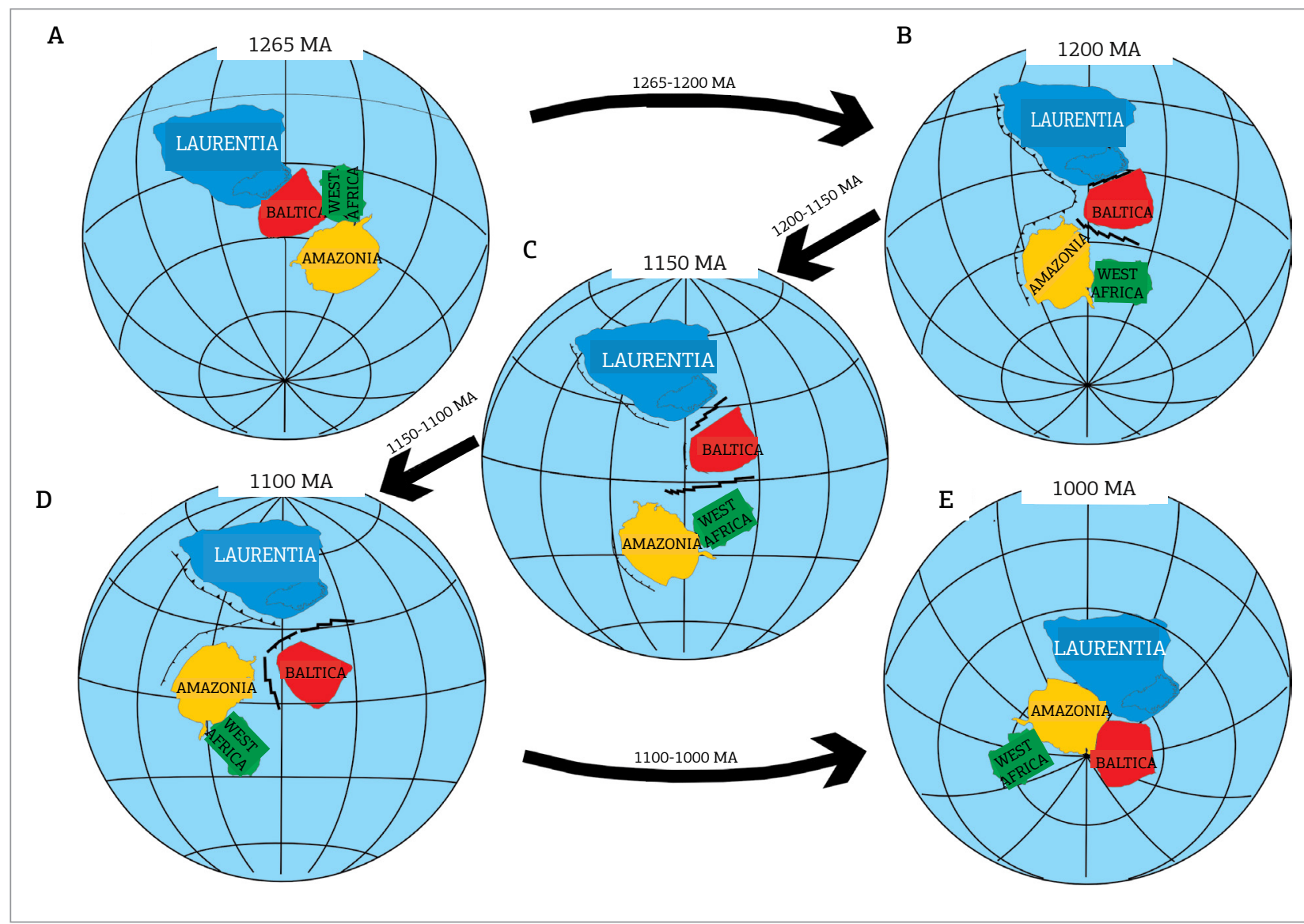

Figure 8. Schematic sketch showing rupture of Columbia core (comprised by Laurentia, Baltica, Amazonia, and West Africa), followed by clockwise rotation of Amazonia/West Africa and Baltica and posterior collision with Laurentia forming Rodínia. (A) Reconstruction at $1265 \mathrm{Ma}$ - Columbia core after Bispo-Santos et al. (2014b) and Pehrsson et al. (2016), positioned by the MacKenzie dykes pole (Buchan \& Halls 1990). (B) Reconstruction at 1200 Ma - Laurentia and Amazonia/West Africa were constrained by the Upper Bylot (Fahrig et al. 1981, Kah et al. 2001) and Nova Floresta poles (Tab. 1), respectively. (C) Reconstruction at $1150 \mathrm{Ma}$ - Laurentia and Amazonia/West Africa were constrained by the Abitibi dykes (Ernst \& Buchan 1993, Krogh et al. 1987, Irving \& Naldrett 1977) and Fortuna Formation poles (Tab. 1), respectively. (D) Reconstruction at $1100 \mathrm{Ma}$ - Laurentia was constrained by the Logan dykes pole (Halls \& Pesonen 1982, Davis \& Sutcliffe 1985). (E) Reconstruction at $1000 \mathrm{Ma}$ - Laurentia, Baltica, and Amazonia as shown in the reconstruction

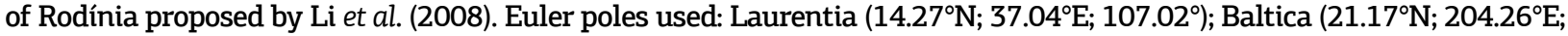
$\left.-176.32^{\circ}\right)$; Amazonia $\left(24.21^{\circ} \mathrm{N} ; 175.25^{\circ} \mathrm{E} ;-150.19^{\circ}\right.$ ). West Africa was rotated to Amazonia as in Bispo-Santos et al. (2014a).

et al. $2014 \mathrm{~b}$ and Pehrsson et al. 2016) constrained by the 1267 Ma MacKenzie dykes pole (Buchan \& Halls 1990). The Baltica-Laurentia link is practically the same as that proposed by Salminen \& Pesonen (2007). It is possible that the MacKenzie dyke swarm is the record of the initial rupture of Columbia (Hou et al. 2008b). Fig. 8B presents the configuration at $1200 \mathrm{Ma}$. Amazonia/West Africa Craton and Laurentia are constrained by Nova Floresta (Tab. 1) and Upper Bylot poles (Fahrig et al. 1981), respectively. Baltica and Amazonia/West Africa broke-up and initiated their clockwise rotation. Fig. 8C shows the configuration at $1150 \mathrm{Ma}$, in which Laurentia and Amazonia/West Africa are constrained by Abitibi dyke (Ernst \& Buchan 1993, Irving \& Naldrett 1977) and Nova Fortuna poles (Tab. 1), respectively. For the reconstruction at $1100 \mathrm{Ma}$ (Fig. 8D), only Laurentia is constrained by Logan sills pole (Halls \& Pesonen 1982, Davis \& Sutcliffe 1985). Finally, Fig. 8E introduces the configuration at $1000 \mathrm{Ma}$ as proposed by Li et al. (2008), in which Rodínia had already been formed.

\section{THE AMAZONIAN CRATON IN GONDWANA}

Dynamic processes associated with the Amazonian Craton, Laurentia, and Proto-Gondwana between $900 \mathrm{Ma}$ and 530 Ma have been intensively investigated and debated. The period when the Amazonian Craton separated from 
Rodínia Supercontinent, as well as the time of its collision with proto-Gondwana, - composed in its western part by the Paranapanema block, the Central Goiás microplate, the Parnaíba block and other smaller blocks underlying the Paraná and Parnaíba Basins - are still in dispute (see Cordani et al. 2013a, 2014, Tohver \& Trindade 2014).

Many authors advocate a final collision between Amazonian-West African Craton and proto-Gondwana at around 650-600 Ma, after closure of the great GoiásPharusian ocean separating these cratonic units in earlier times (e.g. Trompette 1994, 1997, Cordani et al. 2000, Cordani \& Teixeira 2007, Cordani et al. 2013a, 2013b, Ganade de Araújo et al. 2014). In this case, late Neoproterozoic would be characterized by the presence of supercontinent Pannotia (Dalziel 1997), comprising all Gondwana units plus Laurentia, the break-up of Laurentia occurring during the Ediacaran with the formation of the Yapetus Ocean (570 Ma, Cawood et al. 2001). However, Pannotia formation was contested by Meert \& Van der Voo (1997) who declared that Gondwana agglutination occurred in three distinct periods: 800-650 Ma (formation of the Mozambique Belt due to the collision of India, Madagascar, and Sri Lanka with East Africa); 600-530 $\mathrm{Ma}$ (formation of the Brasiliano/Pan-African belts through the collision of the South American and African cratonic blocks); and -550 Ma (formation of the Kuunga belt, which was the result of the collision of Australia and Antarctica with the rest of Gondwana). Thus, east Gondwana would not be completely agglutinated at the time Pannotia is supposed to have existed.

In recent years, several authors have claimed that the final agglutination of the South American core of Gondwana formed by the Amazonia/Rio Apa, Congo-São Francisco, Rio de la Plata and several other smaller blocks - could have happened during the Cambrian between 550-520 Ma, with the closure of the Clymene Ocean that separated the Amazonian Craton from other continental blocks (Trindade et al. 2006).

The paleomagnetic study on carbonate rocks from Araras Group, conducted by Trindade et al. (2003), provided a paleomagnetic pole (Puga Cap carbonate A pole in Tab. 1) for the Amazonian Craton, which has been dated at $627 \pm 30 \mathrm{Ma}$ ( $\mathrm{Pb}-\mathrm{Pb}$ whole rock isochron obtained for rocks at the base of Araras Group - Babinski et al. 2006). When compared with the paleomagnetic poles of proto-Gondwana (including Congo São Francisco and part of East Gondwana), this suggests that the Amazonian Craton was separated from the rest of Gondwana at Ediacaran times. Otherwise, the close fit of the 525 Ma poles from Amazonia and proto-Gondwana (in a Gondwana pre-drift configuration) might show that complete closure of Clymene Ocean occurred only at Ediacaran times (Trindade et al. 2006). In the model proposed by Trindade et al. (2006), West Gondwana was formed diachronically, similarly to the East Gondwana whose final amalgamation occurred only at $525 \mathrm{Ma}$ (Meert \& Van der Voo 1997).

New evidence supporting this interpretation came from paleomagnetic and geochronological studies from remagnetized carbonate rocks collected along the Paraguay Belt (Tohver et al. 2010). Collision along the southeastern margin of the Amazonian Craton along the Paraguay Belt produced folding, trusting, and remagnetization dated at $528 \pm 36 \mathrm{Ma}$. According to Tohver et al. (2010), the oroclinal inflection of the Paraguay Belt occurred after $528 \mathrm{Ma}$, which caused the coherent change observed in the ChRM declinations disclosed for rocks collected in the northern and southern inflection areas. Tohver $e t$ al. (2012) carried out a review regarding the geological, geochronological and tectonic history related to Araguaia, Paraguay and Pampeano belts. These authors show common features for these belts that reflect a shared geodynamic environment associated with the Clymene Ocean closure, with the occurrence of a transition from accumulated cratonic-origin sediments over a passive margin to a predominated magmatic, metamorphic and deformational phase between 550 to $500 \mathrm{Ma}$.

Recently, sedimentologic and provenance studies of rocks from two geological formations of Alto Paraguay Group (Paraguay Belt) showed that their evolutions are associated with the Clymene Ocean closure (Bandeira et al. 2012, McGee et al. 2012, 2015a, 2015b). According to these studies, the top unit of Alto Paraguay Group represents the last transgressive deposits of the Paraguay Basin, resulting from the last stage of marine incursion of this ocean. Meanwhile, pelitic and fine sandstone deposits of Diamantino Formation (Upper Formation from Paraguay Group) are associated with the molassic phase. U-Pb detrital zircons dating of rocks from the basal part of this formation indicates that the deposition of Diamantino Formation occurred after $541 \pm 7 \mathrm{Ma}$ (Bandeira et al. 2012, McGee et al. 2012, 2015a, 2015b). Furthermore, the recent sedimentological and radiometric studies of glaciogenic rocks from Serra Azul Formation (Alto Paraguay Group) indicate that they are probably associated with the 580 Ma Gaskiers event (McGee et al. 2013, 2015a). These findings also propose an Ediacaran-Early Cambrian closure of the Clymene Ocean. The age of $518 \pm 4 \mathrm{Ma}$ (U-Pb zircon) obtained for the post-tectonic São Vicente Granite (Almeida \& Mantovani 1975; McGee et al. 2012) establish the minimal age of the deformation and metamorphic phase in the northern part of Paraguay Belt and, therefore, the final time of the South America accretion in the Gondwana continent.

In a recent paper, however, Ganade de Araújo et al. (2014) discuss that the Goiás-Pharusian ocean separating the AmazonianWest African block from the proto-West Gondwana (also named as Central African block by Cordani et al. 2013a) closed beween 900 and 600 Ma. According to Ganade de Araújo et al. (2014), 
Himalaya-type mountains more than $2500 \mathrm{~km}$ long formed along this mega-suture (the Transbrasiliano-Kandy tectonic corridor, Cordani et al. 2013b), thus producing eclogitic rocks at about $130 \mathrm{~km}$ depth in the lithosphere, whose exhumation occurred at about $615 \mathrm{Ma}$. Unfortunately, paleomagnetic data between 900 and $600 \mathrm{Ma}$ are rare for all Gondwana cratonic blocks, which make the tectonic processes involving Rodínia break-up and Gondwana formation undefiened.

\section{FINAL REMARKS}

In the last decade, a significant increase of the Amazonian paleomagnetic data brought important implications for the geodynamic evolution of the Amazonian Craton and for its participation in supercontinents, mainly in Paleo to Mesoprotezoic times.

The Surumu Group pole corroborated the idea of a ca. 2000-1960 Ma pre-Columbia proto-Amazonian/West Africa link in a continental paleogeography, in which Guri (Guiana Shield) and Sassandra (West Africa Craton) shear zones were aligned. Similarly, the participation of the Amazonian Craton in the SAMBA model, forming the core of Columbia supercontinent, is constrained by the Avanavero pole, which is a model supported by geological and geochronological data (Johansson 2009). A paleogeography at $2000 \mathrm{Ma}$ (Fig. 4) is also envisaged and comprises cratonic blocks that later on formed Laurentia, Baltica, and Amazonian/West Africa in the core of Columbia.

Paleo- to Mesoproterozoic paleomagnetic poles (Colíder, Nova Guarita, Indiavaí, and Salto do Céu poles) from southeastern Amazonian Craton (Brazil-Central Shield) suggest the occurrence of dextral strike-slip movements between the Guiana and the Brazil-Central Shields. These transcurrent movements could be due to the collision of the Paraguá Terrain with proto-Amazonia along the Alto Guaporé Belt at ca. $1320 \mathrm{Ma}$ ago, although other tectonic events (Sunsás, Nova Brasilândia and Aguapeí orogens) may also be responsible for them. Another possible interpretation is that internal block rotations within Columbia supercontinent occurred between $1790 \mathrm{Ma}$ (or $1530 \mathrm{Ma}$ ) and $1420 \mathrm{Ma}$ ago (see Fig. 6).
The importance of Nova Guarita and Indiavaí poles should be highlighted for the significance of the E-W NBB whose origin resulted, most probably, of intracratonic reactivation that occurred during the collision of the Amazonian Craton with Laurentia along the Sunsás/Grenville Belt. Paleomagnetic data from late Mesoproterozoic and early Neoproterozoic are compatible with two scenarios for the collision of the Amazonian Craton with Laurentia in the formation of Rodínia: oblique collision, followed by relative transcurrent movement up to the collision of Amazonian Craton with Baltica at ca. $1000 \mathrm{Ma}$ (Fig. 7), or starting from a SAMBA link, a clockwise rotation of Amazonia/West Africa Craton and Baltica with their final collision with Laurentia along the Grenville Belt (Fig. 8).

Finally, some geochronological and paleomagnetic data suggest that the collision of the Amazonian-West African Craton (plus Rio Apa block) with proto-Gondwana resulted in the formation of Gondwana only in the late Ediacaran and early Cambrian between 550 and $520 \mathrm{Ma}$. However, this hypothesis is contested by other geologic-geochronological evidence, which defend a prior (650-600 Ma) collision. We understand that only with more key paleomagnetic poles from Gondwana cratonic units in the interval between 900 and $550 \mathrm{Ma}$, we will be able to solve this issue.

\section{ACKNOWLEDGEMENTS}

This work is a synthesis of more than ten years of research on the Amazonian craton, and it has benefited from discussions with several colleagues from Universidade de São Paulo, Serviço Geológico do Brasil(CPRM), Companhia Mato-Grossense de Mineração (METAMAT), Universidade Federal do Mato Grosso (UFMT), Instituto Nacional de Ciência e Tecnologia de Geociências da Amazônia (INCT-GEOCIAM), among others. We thank the support provided by research agencies, institutions, and professionals that contributed to the progress of paleomagnetic research in the Amazonian Craton: grants 2007/59531-4, 2007/53177-4, 2011/50887-6 and 2012/50327-3, São Paulo Research Foundation (FAPESP), and grant 554458/2005-5 (CNPq).

\section{REFERENCES}

Åhäll K.I. \& Connelly J. 1998. Intermittent 1.53-1.13 Ga magmatism in Western Baltica; age constraints and correlations within a postulated supercontinent. Precambrian Research, 92:1-20.

Almeida F.F.M. \& Mantovani M.S.M. 1975. Geologia e gechronologia do granito de São Vicente, Mato Grosso. Anais da Academia Brasileira de Ciências, 47:451-458.

Almeida M.E., Costa U.A.P., Betiollo L.M., Reis N.J., Splendor F., Bahia R.B.C., Ruffet G. 2012. Idades Ar-Ar step heating em milonitos do sudeste do Amazonas: implicações na evolução tectonotermal da Província Rondônia-Juruena. In: $46^{\circ}$ Congresso Brasileiro de Geologia, Abstract, CD-ROM, Santos, São Paulo, Brasil.

Anderson J.L. \& Morrison L. 1992. The role of anorogenic granites in the Proterozoic crustal development of North America. In: Condie K.C. (ed.). Proterozoic Crustal Evolution. Amsterdam, Elsevier, p. 263-299.

Araújo-Ruiz L.M.B., Godoy A.M., Ruiz A.S., Sousa M.Z.A., Montano L.F.M. 2007. Geologia e geoquímica do Batólito Rapakivi Rio Branco, SW do Cráton Amazônico - MT. Geologia USP Série Científica, 7:57-72. 
As J.A. \& Zijderveld J.D.A. 1958. Magnetic cleaning of rocks in palaeomagnetic research. Geophysical Journal, 1:308-319.

Babinski M., Trindade R.I.F., Alvarenga C.J.S., Boggiani P.C., Liu D., Santos R.V., Brito Neves B.B. 2006. Chronology of Neoproterozoic ice ages in Central Brazil. In: V South American Symposium on Isotope Geology, Punta del Este, Uruguay, Short Papers, p. 303-306.

Bandeira J., McGee B., Nogueira A.C.R., Collins A.S., Trindade R.I.F. 2012. Sedimentological and provenance response to Cambrian closure of the Clymene ocean: the upper Alto Paraguai Group, Paraguay belt, Brazil. Gondwana Research, 21:323-340.

Bettencourt J.S., Tosdal R.M., Leite Jr. W.B., Payolla B.L. 1999. Mesoproterozoic rapakivi granites of the Rondônia Tin Province, southwestern border of the Amazonian Craton, Brazil - I. Reconnaissance U-Pb geochronology and regional implications. Precambrian Research, 95:41-67.

Bettencourt J.S., Leite Jr. W., Payolla B., Ruiz A.S., Matos R.S., Tosdal R.M. 2010. The Rondonian-San Ignacio Province in the SW Amazonian Craton: an overview. Journal of South American Earth Sciences, 29:28-46

Beyer S.R., Hiatt E.E., Kyser K., Drever G.L., MarlattJ. 2015. Stratigraphy, diagenesis and geological evolution of the Paleoproterozoic Roraima Basin, Guyana: Links to tectonic events on the Amazon Craton and assessment for uranium mineralization potential. Precambrian Research, 267:227-249.

Bispo-Santos F. 2012. Estudo paleomagnético de unidades paleoproterozóicas do Cráton Amazônico. Dissertation, Universidade de São Paulo, São Paulo, 253 p.

Bispo-Santos F., D’Agrella-Filho M.S., Pacca I.I.G., Janikian L., Trindade R.I.F., Elming S-Á., Silva J.A., Barros M.A.S., Pinho F.E.C. 2008. Columbia revisited: Paleomagnetic results from the 1790 Ma Colíder volcanics (SW Amazonian Craton, Brazil). Precambrian Research, 164:40-49.

Bispo-Santos F., D’Agrella-Filho M.S., Trindade R.I.F., Elming S-Á., Janikian L., Vasconcelos P.M., Perillo B.M., Pacca I.I.G., Silva J.A., Barros M.A.S. 2012. Tectonic implications of the 1419 Ma Nova Guarita mafic intrusives paleomagnetic pole (Amazonian Craton) on the longevity of Nuna. Precambrian Research, 196-197:1-22.

Bispo-Santos F., D’Agrella-Filho M.S., Janikian L., Reis N.J., Reis M.A.A.A., Trindade R.I.F. 2014a. Towards Columbia: Paleomagnetism of 1980-1960 Ma Surumu volcanic rocks, Northern Amazonian Craton. Precambrian Research, 244:123-138.

Bispo-Santos F., D’Agrella-Filho M.S., Trindade R.I.F., Janikian L., Reis N.J. 2014b. Was there SAMBA in Columbia? Paleomagnetic evidence from 1790 Ma Avanavero mafic sills (Northern Amazonian craton). Precambrian Research, 244:139-155.

Bleeker W. 2003. The late Archean record: a puzzle in ca. 35 pieces. Lithos, 71:99-134.

Bogdanova S.V., Page L.M., Skridlaite G., Taran L.N. 2001. Proterozoic tectonothermal history in the western part of the east European Craton: ${ }^{40} \mathrm{Ar} /{ }^{39} \mathrm{Ar}$ geochronological constraints. Tectonophysics, 339:39-66.

Bogdanova S.V., Gintov O.B., Kurlovich D.M., Lubnina N.V., Nilsson M.K.M., Orlyuk M.I.O., Pashkevich I.K., Shumlyanskyy L.V., Starostenko V.I. 2013. Late Palaeoproterozoic mafic dyking in the Ukranian Shield of Volgo-Sarmatia caused by rotation during the assembly of supercontinent Columbia (Nuna). Lithos, 174:196-216.

Boger S.D., Raetz M., Giles D., Etchart E., Fanning C.M. 2005. U-Pb age data from Sunsas region of Eastern Bolivia, evidence for the allochthonous origin of the Paraguá Block. Precambrian Research, 139:121-146.

Bonilla-Pérez A., Frantz J.C., Charão-Marques J., Cramer T., FrancoVictoria J.A., Mulocher E., Amaya-Perea Z. 2013. Petrografia, geoquimica y geocronologia del Granito de Parguaza en Colombia. Boletín de Geología, 35:83-104

Brito Neves B.B., Sá J.M., Nilson A.A., Botelho N.F. 1995. A Tafrogênese Estateriana nos blocos Paleoproterozóicos da América do Sul e processos subseqüentes. Geonomos, 3(2):1-21.

Buchan K.L. \& Halls H.C. 1990. Paleomagnetism of Proterozoic mafic dyke swarms of the Canadian Shiled. In: Parker A.J., Rickwood P.C., Tucker D.H. (eds.). Mafic dykes and emplacement mechanism. A.A. Balkema, Rotterdam, p. 209-230.

Buchan K.L., Mertanen S., Park R.G., Pesonen L.J., Elming S-A., Abrahamsen N., Bylund G. 2000. Comparing the drift of Laurentia and Baltica in the Proterozoic: the importance of key palaeomagnetic poles. Tectonophysics, 319:167-198.

Buchan K.L., Mortensen J.K., Card K.D., Percival J.A. 1998. Paleomagnetism and U-Pb geochronology of diabase dyke swarms of Minto Block, Superior Province, Quebec, Canada. Canadian Journal of Earth Sciences, 35:1054-1110.

Bullard E., Everett J.E., Smith A.G. 1965. The fit of the continents around the Atlantic. Philosophical Transactions of the Royal Society of London A: Mathematical, Physical and Engineering Sciences, 258:41-51

Butler R.F. 1992. Paleomagnetism: magnetic domains to geologic terranes. Boston, Blackwell Scientific Publications, 319 p.

Castillo J.H. \& Costanzo-Alvarez V. 1993. Paleomagnetism of the Uairen Formation, Roraima Group, southeastern Venezuela: evidence for one of the oldest (Middle Proterozoic) depositional remanent magnetizations. Canadian Journal of Earth Sciences, 30:2380-2388.

Cawood P.A., McCausland P.J.A., Dunning G.R. 2001. Opening Iapetus: Constraints from the Laurentian margin in Newfoundland. Geological Society of America Bulletin, 113:443-453.

Condie K.C. 2002. Continental growth during a 1.9-Ga superplume event. Journal of Geodynamics, 34:249-264.

Cordani U.G. \& Teixeira W. 2007. Proterozoic accretionary belts in the Amazonian Craton. Geological Society, America Memoir, 200:297-320.

Cordani U.G., Tassinari C.C.G., Teixeira W., Basei M.A.S., Kawashita K. 1979. Evolução tectônica da Amazônia com base nos dados geocronológicos. In: Congreso Geológico Chileno, Arica, Actas, v. 4, p. 137-148.

Cordani U.G., Sato K., Teixeira W., Tassinari C.C.G., Basei M.A.S. 2000. Crustal evolution of the South American platform. In: Cordani U.G., Milani E.J., Thomaz-Filho A., Campos D.A. (eds.) Tectonic evolution of South America, Rio de Janeiro, p. 19-40.

Cordani U.G., D’Agrella-Filho M.S., Brito-Neves B.B., Trindade R.I.F. 2003. Tearing up Rodinia: the Neoproterozoic paleogeography of South American fragments. Terra Nova, 15:350-359.

Cordani U.G., Teixeira W., D’Agrella-Filho M.S., Trindade R.I.F. 2009. The position of the Amazonian craton in supercontinents. Gondwana Research, 15:396-407

Cordani U.G., Fraga L.M., Reis N., Tassinari C.C.G., Brito-Neves B.B. 2010. On the origin and tectonic significance of the intra-plate events of Grenvillian-type age in South America: a discussion. Journal of South American Earth Sciences, 29:143-159.

Cordani U.G., Pimentel M.M., Araújo C.E.G., Basei M.A.S., Fuck R.A., Girardi V.A.V. 2013a. Was there an ediacaran Clymene Ocean in central South America? American Journal of Science, 313:517-539.

Cordani U.G., Pimentel M.M., Araújo C.E.G., Fuck R.A. 2013b. The significance of the Transbrasiliano-Kandy tectonic corridor for the amalgamation of West Gondwana. Brazilian Journal of Geology, 43:583-597. 
Cordani U.G., Pimentel M.M., De Araújo C.E.G., Basei M.A.S., Fuck R.A., Girardi V.A.V. 2014. Reply to the comment by Tohver E., Trindade R.I.F., on was there a clymene ocean in central South America? 313: 517-539. American Journal of Science, 314(3):814-819.

D'Agrella-Filho M.S., Trindade R.I.F., Siqueira R., Ponte-Neto C.F., Pacca I.I.G. 1998. Paleomagnetic constraints on the Rodinia supercontinent: Implications for its Neoproterozoic break-up and the formation of Gondwana. International Geology Review, 40:171-188.

D’Agrella-Filho M.S., Pacca I.G., Trindade R.I.F., Teixeira W., Raposo M.I.B., Onstott T.C. 2004. Paleomagnetism and ${ }^{40} \mathrm{Ar} /{ }^{39} \mathrm{Ar}$ ages of mafic dykes from Salvador (Brazil): new constraints on the São Francisco Craton APW path between 1080 and 1010 Ma. Precambrian Research, 132:55-77.

D’Agrella-Filho M.S., Tohver E., Santos J.O.S., Elming S-Á., Trindade R.I.F., Pacca I.G., Geraldes M.C. 2008. Direct dating of paleomagnetic results from Precambrian sediments in the Amazon craton: Evidence for Grenvillian emplacement of exotic crust in SE Appalachians of North America. Earth and Planetary Science Letters, 267:188-199.

D’Agrella-Filho M.S., Trindade R.I.F., Tohver E., Janikian L., Teixeira W.

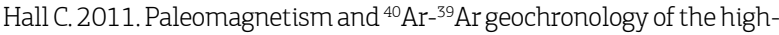
grade metamorphic rocks of the Jequié block, São Francisco Craton: Atlantica, Ur and beyond. Precambrian Research, 185:183-201.

D’Agrella-Filho M.S., Trindade R.I.F., Elming S-Á., Teixeira W., Yokoyama E., Tohver E., Geraldes M.C., Pacca I.I.G., Barros M.A.S., Ruiz A.S. 2012. The 1420 Ma Indiavaí Mafic Intrusion (SW Amazonian Craton): Paleomagnetic results and implications for the Columbia supercontinent. Gondwana Research, 22:956-973.

D’Agrella-Filho M.S., Trindade R.I.F., Queiroz M.V.B., Meira V.T., Janikian L., Ruiz A.S., Bispo-Santos F. 2016. Reassessment of Aguapeí (Salto do Céu) Paleomagnetic pole of the Amazonian Craton and implications for Proterozoic supercontinents. Precambrian Research, 272:1-17.

Daly J.S., Balagansky V.V., Timmerman M.J., Whitehouse M.J. 2006. The Lapland-Kola orogen: Palaeoproterozoic collision and accretion of the northern Fennoscandian lithosphere. In: Gee D.G. \& Stephenson R.A. (eds.) European Lithosphere Dynamics. Geological Society, 32, London, Memoirs, p. 579-598.

Dalziel I.W.D. 1997. Neoproterozoic-Paleozoic geography and tectonics: Review, hypothesis, environmental speculation. Geological Society of America Bulletin, 109:16-42.

Dalziel I.W.D., Mosher S., Gahagan L.M. 2000. Laurentia-Kalahari collision and the assembly of Rodinia. The Journal of Geology, 108:499-513.

Davis D.W. \& Sutcliffe R.H. 1985. U-Pb ages from the Nipigon plate and northern Lake Superior. Geological Society of America Bulletin, 96:1572-1579.

de Kock M.O., Evans D.A.D., Beukes N.J. 2009. Validating the existence of Vaalbara in the Neoarchean. Precambrian Research, 174:145-154.

Delor C., Lahondere D., Egal E., Lafon J.M., Cocherie A., Guerrot C., Rossi P., Truffert C., Theveniaut H., Phillips D., Avelar V.G. 2003. Transamazonian crustal growth and reworking as revealed by the 1:500.000 - scale geological map of French Guiana. In Geologie de la France - Special Guiana Shield, 2. ed., BRGM, SGF Editor, p. 5-58.

Elming S-Á., D’Agrella-Filho M.S., Page L.M., Tohver E., Trindade R.I.F., Pacca I.I.G., Geraldes M.C., Teixeira W. 2009. A palaeomagnetic and ${ }^{40} \mathrm{Ar} /{ }^{39} \mathrm{Ar}$ study of Late Precambrian sills in the SW part of the Amazonian Craton: Amazonia in the Rodinia reconstruction. Geophysical Journal International, 178:106-122.

Elming S-Å., Shumlyanskyy L., Kravchenko S., Layer P., Söderlund U. 2010. Proterozoic basic dykes in the Ukrainian Shield: A palaeomagnetic, geochronologic and geochemical study-The accretion of the Ukrainian Shield to Fennoscandia. Precambrian Research, 178:119-135.

Enjolvy R. 2004. Caractérisation géochronologique et pétrologique de l'évènement fini-transamazonien: étude en Guyane française et en Amapá (Brésil). Rapport de DEA, Université de Montpellier II, 42 p.

Ernst R.E. \& Buchan K.L. 1993. Paleomagnetism of the Abitibi dyke swarm, southern Superior Province and implications for the Logan Loop. Canadian Journal of Earth Sciences, 30:1886-1897.

Evans D.A.D. 2013. Reconstructing pre-Pangean supercontinents. Geological Society of America Bulletin, 125:1735-1751.

Evans D.A.D. \& Halls H.C. 2010. Restoring Proterozoic deformation within the Superior craton. Precambrian Research, 183:474-489.

Evans D.A.D. \& Mitchell R.N. 2011. Assembly and breakup of the core of Paleoproterozoic-Mesoproterozoic supercontinent Nuna. Geology, 39:443-446.

Fahrig W.F., Christie K.W., Jones D.L. 1981. Paleomagnetism of the Bylot basins: evidence for MacKenzie continental tensional tectonics. Geological Survey of Canada Paper, 81-10:303-312.

Fedotova M.A., Khramov N.A., Pisakin B.N., Priyatkin A.A. 1999. Early Proterozoic palaeomagnetism: new results from the intrusives and related rocks of the Karelian, Belomorian and Kola provinces, eastern Fennoscandian Shield. Geophysical Journal International, 137:691-712.

Fraga L. \& Dreher A. 2010. Grupo Surumu. In: CPRM (ed.) Programa Geologia do Brasil. Programa Cartografia da Amazônia. Geologia e Recursos Minerais da Folha Vila de Tepequém, NA, 80-94.

Ganade de Araújo C.E.G., Rubatto D., Hermann J., Cordani U.G., Caby R., Basei M.A.S. 2014. Ediacaran 2.500-km-long synchronous deep continental subduction in the West Gondwana orogen. Nature Communications, 5(5198):1-8.

Gaudette H.E., Mendoza V., Hurley P.M., Fairbairn H.W. 1978. Geology and age of the Parguaza rapakivi granite, Venezuela. Geological Society of America Bulletin, 89:1335-1340.

Geraldes M.C., Van Schmus W.R., Condie K.C., Bell S., Teixeira W. Babinski M. 2001. Proterozoic geologic evolution of the SW part of the Amazonian Craton in Mato Grosso state, Brazil. Precambrian Research, 111:91-128.

Geraldes M.C., Nogueira C., Vargas-Mattos G., Matos R., Teixeira W., Valencia V., Ruiz J. 2014. U-Pb detrital zircon ages from the Aguapeí Group (Brazil): Implications for the geological evolution of the SW border of the Amazonian Craton. Precambrian Research, 244(1):306-316.

Gibbs A.K. 1987. Contrasting styles of continental mafic intrusions in the Guiana Shield. In: Halls H.C. \& Fahrig W.F. (eds.) Mafic dyke swarms. Geological Association of Canada, Special paper, 34:457-465.

Girardi V.A.V., Corrêa da Costa P.C., Teixeira W. 2012. Petrology and Sr-Nd characteristics of the Nova Lacerda dike swarm, SW Amazonian Craton: new insights regarding its subcontinental mantle source and Mesoproterozoic geodynamics. International Geology Review, 54(2):165-182.

Gower C.F., Ryan A.F., Rivers T. 1990. Mid-Proterozoic LaurentiaBaltica: an overview of its geological evolution and summary of the contributions made by this volume. In: Gower C.F., Rivers T., Ryan B. (eds.) Mid Proterozoic Laurentia-Baltica. Geological Association of Canada, St. John's Newfoundland, p. 23-40.

Halls H.C. \& Pesonen L.J. 1982. Paleomagnetism of Keweenawan rocks. Geological Society of America Memoirs, 156:173-201.

Hawkesworth C.J., Dhuime B., Pietranik A.B., Cawood P.A., Kemp A.I.S. Storey C.D. 2010. The generation and evolution of the continental crust. Journal of the Geological Society, 167:229-248. 
Hoffman P.F. 1989. Speculations on Laurentia's first gigayear (2.0 to $1.0 \mathrm{Ga})$. Geology, 17:135-138.

Hoffman P.F. 1991. Did the breakout of Laurentia turn Gondwanaland inside-out? Science, 252:1409-1412.

Hoffman P.F. 1997. Tectonic genealogy of North America. In: van der Pluijm B.A. \& Marshak S. (eds.) An introduction to structural geology and tectonics. McGraw Hill, New York, p. 459-464.

Hou G., Santosh M., Qian X., Lister G.S., Li J. 2008a. Configuration of the Late Paleoproterozoic supercontinent Columbia: Insights from radiating mafic dyke swarms. Gondwana Research, 14:395-409.

Hou G., Santosh M., Qian X., Lister G.S., Li J. 2008b. Tectonic constraints on $1.3 \sim 1.2$ Ga final breakup of Columbia supercontinent from a giant radiating dyke swarm. Gondwana Research, 14:561-566.

Ibanez-Mejia M., Ruiz J., Valencia V.A., Cardona A., Gehrels G.E., Mora A.R. 2011. The Putumayo Orogen of Amazonia and its implications for Rodinia reconstructions : New U-Pb geochronological insights into the Proterozoic tectonic evolution of northwestern South America. Precambrian Research, 191:58-77.

Irving E. \& Naldrett A.J. 1977. Paleomagnetism in Abitibi greenstone belt, and Abitibi and Matachewan diabase dykes: evidence of the Archean geomagnetic field. The Journal of Geology, 85:157-176.

Johansson A. 2009. Baltica, Amazonia and the SAMBA connection - 1000 million years of neighbourhood during the Proterozoic? Precambrian Research, 175:221-234.

Johansson $\AA$. 2014. From Rodinia to Gondwana with the 'SAMBA' model - a distant view from Baltica towards Amazonia and beyond. Precambrian Research, 244:226-235.

Kah L.C., Lyons T.W., Chesley J.T. 2001. Geochemistry of a $1.2 \mathrm{Ga}$ carbonate-evaporite succession, northern Baffin and Bylot Islands: implications for Mesoproterozoic marine evolution. Precambrian Research, 111:203-234.

Karlstrom K., Åhäll K.I., Harlan S.S., Williams M.L., McLelland J., Geissman J.W. 2001. Long-Lived (1.8-1.0 Ga) convergent orogen in southern Laurentia, its extensions to Australia and Baltica, and implications for refining Rodinia. Precambrian Research, 111:5-30.

Krogh T.E., Corfu F., Davis D.W., Dunning G.R., Heaman L.M., Kamo S.L., Machado N., Greenough J.D., Nakamura E. 1987. Precise U-Pb isotopic ages of diabase dyke and mafic to ultramafic rocks using trace amounts of baddeleyite and zircon. In: Halls H.C. \& Fahrig W.F. (eds.) Mafic dyke swarms. Geological Association of Canada, Special Paper, 34, p. 147-152.

Kröner T.M. \& Cordani U.G. 2003. African, southem India and South American cratons were not part of the Rodinia supercontinent: evidence from field relationships and geochronology. Tectonophysics, 375:325-352.

Kusky T.M., Li J., Santosh M. 2007. The Paleoproterozoic North Hebei Orogen: North China craton's collisional suture with the Columbia supercontinent. Gondwana Research, 12:4-28.

Lacerda-Filho J.V., Abreu Filho W., Valente C.R., Oliveira C.C., Albuquerque M.C. 2004. Geologia e Recursos Minerais do Estado do Mato Grosso. Escala 1:1.000.000. Texto explicativo dos mapas geológicos e de recursos minerais do Estado do Mato Grosso, Convênio CPRM e SICME-MT, 235 p.

Ledru P., Cocherie A., Barbosa J., Johan V., Onstott T. 1994. Ages du métamorphisme granulitique dans le craton du São Francisco (Brésil). Implications sur la nature de l'orogène transamazonien. Comptes Rendus de l'Academie des Sciences, Paris II, 318:251-257.

Leite J.A.D. \& Saes G.S. 2003. Geocronologia Pb/Pb de zircões detríticos e análise estratigráfica das coberturas sedimentares
Proterozóicas do sudeste do Craton Amazônico. Revista do Instituto de Geociências da USP, 3:113-127.

Li Z.X., Bogdanova S.V., Collins A.S., Davidson A., De Waele B., Ernst R.E., Fitzsimons I.C.W., Fuck R.A., Gladkochub D.P., Jacobs J., Karlstrom K.E., Lu S., Natapov L.M., Pease V., Pisarevsky S.A., Thrane K., Vernikovsky V. 2008. Assembly, configuration, and break-up history of Rodinia: A synthesis. Precambrian Research, 160:179-210.

Litherland M., Annells R.N., Darbyshire D.P.F., Fletcher C.J.N., Hawkins M.P., Klinck B.A., Mitchell W.I., O'Connor E.A., Pitfield P.E.J., Power G., Webb B.C. 1989. The Proterozoic of Eastern Bolivia and its relationship to the Andean mobile belt. Precambrian Research, 43:157-174.

Lubnina N.V., Stepanova A.V., Ernst R.E., Nilsson M., Söderlund U. 2016. New U-Pb baddeleyite age, and AMS and paleomagnetic data for dolerites in the Lake Onega region belonging to the 1.98-1.95 Ga regional Pechenga-Onega Large Igneous Province. GFF, 138(1):54-78.

McGee B., Collins A.S., Trindade R.I.F. 2012. G'day Gondwana the final accretion of a supercontinent: U-Pb ages from the postoroigenic São Vicente Granite, northern Paraguay Belt, Brazil. Gondwana Research, 21:316-322.

McGee B., Collins A.S., Trindade R.I. 2013. A glacially incised canyon in Brazil: Further evidence for mid-Ediacaran glaciation? The Journal of Geology, 121(3):275-287.

McGee B., Collins A.S., Trindade R.I.F., Jourdan F. 2015a. Investigating mid-Ediacaran glaciation and final Gondwana amalgamation using coupled sedimentology and ${ }^{40} \mathrm{Ar}-{ }^{39} \mathrm{Ar}$ detrital muscovite provenance from the Paraguay Belt, Brazil. Sedimentology, 62:130-154.

McGee B., Collins A.S., Trindade R.I., Payne J. 2015b. Age and provenance of the Cryogenian to Cambrian passive margin to foreland basin sequence of the northern Paraguay Belt, Brazil. Geological Society of America Bulletin, 127(1-2):76-86.

McMenamim M.A.S. \& McMenamim D.L.S. 1990. The emergence of animals: the Cambrian breakthrough. Columbia University Press, New York, 217 p.

Meert J.G. 2002. Paleomagnetic Evidence for a Paleo-Mesoproterozoic Supercontinent Columbia. Gondwana Research, 5:207-215.

Meert J.G. 2009. Palaeomagnetism: In GAD we trust. Nature Geoscience, 2(10):673-674.

Meert J.G. 2012. What's in a name? The Columbia (Paleopangaea/ Nuna) supercontinent. Gondwana Research, 21:987-993.

Meert J.G. \& Van der Voo R. 1997. The assembly of Gondwana 800550Ma. Journal of Geodynamics, 23:223-235.

Meert J.G. \& Torsvik T.H. 2003. The making and unmaking of a supercontinent: Rodinia revisited. Tectonophysics, 375:261-288.

Mitchell R.N., Bleeker W., van Breemen O., Lecheminant T.N., Peng P., Nilsson M.K.M., Evans D.A.D. 2014. Plate tectonics before 2.0 Ga: Evidence from Paleomagnetism of cratons within Supercontinent Nuna. American Journal of Science, 314:878-894.

Nadeau S., Chen W., Reece J., Lachhman D., Ault R., Faraco M.T.L., Fraga L.M., Reis N.J., Betiollo L.M. 2013. Guyana: The lost hadean crust of South America? Brazilian Journal of Geology, 43(4):601-606.

Nomade S., Chen Y., Féraud G., Pouclet A., Théveniaut H. 2001. First paleomagnetic and ${ }^{40} \mathrm{Ar} /{ }^{39} \mathrm{Ar}$ study of Paleoproterozoic rocks from the French Guyana (Camopi and Oyapok rivers), northeastern Guyana Shield. Precambrian Research, 109:239-256.

Nomade S., Chen Y., Pouclet A., Féraud G., Théveniaut H., Daouda B.Y., Vidal M., Rigolet C. 2003. The Guiana and West African Shield Palaeoproterozoic grouping: new palaeomagnetic data for French Guiana and Ivory Coast. Geophysical Journal International, 154:677-694. 
Onstott T.C. \& Hargraves R.B. 1981. Proterozoic transcurrent tectonics: palaeomagnetic evidence from Venezuela and Africa. Nature, 289:131-136.

Onstott T.C. \& Dorbor J. 1987. ${ }^{40} \mathrm{Ar} /{ }^{39} \mathrm{Ar}$ and paleomagnetic results from Liberia and the Precambrian APW data base for the West African Shield. Journal of African Earth Sciences, 6:537-552.

Onstott T.C., Hargraves R.B., York D. 1984a. Dating of Precambrian diabase dykes of Venezuela using Paleomagnetic and ${ }^{40} \mathrm{Ar} /{ }^{39} \mathrm{Ar}$ methods. Anais II do Simpósio Amazônico, Manaus, Brasil, DNPM, 2:513-518.

Onstott T.C., Hargraves R.B., York D., Hall C. 1984b. Constraints on the motions of South American and African shields during the Proterozoic: I. ${ }^{40} \mathrm{Ar} /{ }^{39} \mathrm{Ar}$ and paleomagnetic correlations between Venezuela and Liberia. Geological Society of America Bulletin, 95:1045-1054.

Onstott T.C., Hall C.M., York D. 1989. ${ }^{40} \mathrm{Ar} /{ }^{39} \mathrm{Ar}$ thermochronometry of the Imataca Complex, Venezuela. Precambrian Research, 42:255-291.

Pehrsson S.J., Eglington B.M., Evans D.A.D., Huston D., Reddy S. 2016. Metallogeny and its link to orogenic style during the Nuna supercontinent cycle. In: Li Z.X., Evans D.A.D., Murphy J.B. Supercontinent Cycles Through Earth History. Geological Society, London, Special Publications, 424:83-94

Pesonen L.J., Elming S.A., Mertanen S., Pisarevsky S., D’AgrellaFilho M.S., Meert J.G., Schmidt P.W., Abrahamsen N., Bylund G. 2003. Palaeomagnetic configuration of continents during the Proterozoic. Tectonophysics, 375:289-324.

Pesonen L.J., Mertanen S., Veikkolainen T. 2012. Paleo-Mesoproterozoic Supercontinents - A paleomagnetic view. Geophysica, 47:5-47.

Pinho M.A.S.B., Chemale Jr F., Van Schmus W.R., Pinho F.E.C. 2003. U-Pb and Sm-Nd evidence for 1.76-1.77 Ga magmatism in the Moriru region, Mato Grosso, Brazil: Implications for province boundaries in the SW Amazon Craton. Precambrian Research, 126:1-25.

Piper J.D.A. 2010. Protopangea: Palaeomagnetic definition of Earth 's oldest (mid-Archaean-Palaeoproterozoic) supercontinent. Journal of Geodynamics, 50:154-165.

Piper J.D.A. \& Lomax K. 1973. Palaeomagnetism of Precambrian Birrimian and Tarkwaian rocks of West Africa. Geophysical Journal of the Royal Astronomical Society, 34:435-450.

Pisarevsky S.A. \& Bylund G. 2010. Paleomagnetism of 1780$1770 \mathrm{Ma}$ mafic and composite intrusions of Småland (Sweden): Implications for the Mesoproterozoic Supercontinent. American Journal of Science, 310:1168-1186.

Pisarevsky S.A., Wingate M.T.D., Powell C., Johnson S., Evans D.A.D. 2003. Models of Rodinia assembly and fragmentation. In: Yoshida M. (ed.) Proterozoic East Gondwana : Supercontinent Assembly and Breaup. Geological Society, London, Special Publications, 206:35-55.

Pisarevsky S.A., Elming S- $\AA$., Pesonen L.J., Li Z.X. 2014 Mesoproterozoic paleogeography: Supercontinent and beyond. Precambrian Research, 244:207-225.

Rämö O.T., McLemore V.T., Hamilton M.A., Kosunen P.J., Heizler M., Haapala I. 2003. Intermittent 1630-1220 Ma magmatism in central Mazatzal Province: new geochronologic piercing points and some tectonic implications. Geology, 31:335-338.

Reddy S.M., Evans D.A.D. 2009. Palaeoproterozoic supercontinents and global evolution: correlations from core to atmosphere. In: Reddy S.M., Mazunder R., Evans D.A.D., Collins A.S. (eds.) Palaeoproterozoic Supercontinents and Global Evolution. Geological Society of London, Special Publications, 323:1-26

Reis N.J., Fraga L.M.B., Faria M.S.G., Almeida M.E. 2003. Geologia do Estado de Roraima, Brasil. In: Geology of France and Surrounding Areas - Special Guiana Shield, BRGM, (2-3-4):121-134.
Reis N.J., Teixeira W.,Hamilton M.A.,Bispo-Santos F., Almeida M.E., D’AgrellaFilho M.S. 2013. The Avanavero mafic magmatism, a late Paleoproterozoic LIP in the Guiana Shield, Amazonian Craton: U-Pb TIMS baddeleyite, geochemical and paleomagnetic evidence. Lithos, 174:175-195.

Rizzotto G.J. \& Hartmann L.A. 2012. Geological and geochemical evolution of the Trincheira Complex, a Mesoproterozoic ophiolite in the southwestern Amazon craton, Brazil. Lithos, 148:277-295.

Rogers J.J.W. 1996. A history of continents in the past three billion years. The Journal of Geology, 104:91-107.

Rogers J.J.W. \& Santosh M. 2002. Configuration of Columbia, a Mesoproterozoic Supercontinent. Gondwana Research, 5:5-22.

Rogers J.J.W. \& Santosh M. 2009. Tectonics and surface effects of the supercontinent Columbia. Gondwana Research, 15:373-380.

Ruiz A.S. 2005. Evolução geológica do Sudoeste do Cráton Amazônico na região limítrofe Brasil-Bolívia. PhD Thesis, Universidade Estadual Paulista, Rio Claro, 259 p.

Sadowski G.R. \& Bettencourt J.S. 1996. Neoproterozoic tectonic correlations between east Laurentia and the western border of the Amazon Craton. Precambrian Research, 76:213-227.

Salminen J. \& Pesonen L.J. 2007. Paleomagnetic and rock magnetic study of the Meso-proterozoic sill, Valaam island, Russian Karelia. Precambrian Research, 159:212-230.

Santos J.O.S., Hartmann L.A., Gaudette H.E., Groves D.I., McNaugthon N.J., Fletcher I.R. 2000. A new understanding of the Provinces of Amazon Craton based on integration of field mapping and U-Pb and Sm-Nd geochronology. Gondwana Research, 3:453-488.

Santos J.O.S., Rizzotto G.A., Hartmann L.A., McNaughton N.J., Fletcher L.R. 2001. Ages of sedimentary basins related to the Sunsas and Juruena orogenies, Southwest Amazon Craton established by zircon U-Pb geochronology. In: Workshop Geology of the SW Amazonian Craton: State-of-the-Art. Extended Abstract, São Paulo, p. 114-118.

Santos J.O.S, Potter P.E., Reis N.J., Hartmann L.A., Fletcher I.R. McNaughton N.J. 2003. Age, source, and regional stratigraphy of the Roraima Supergroup and Roraima-like outliers in northern South America based on U-Pb geochronology. Geological Society of America Bulletin, 3:331-348.

Santos J.O.S., Rizzotto G.J., Potter P.E., McNaughton N.J., Matos R.S., Hartmann L.A., Chemale Jr. F., Quadros M.E.S. 2008. Age and autochthonous evolution of the Sunsás Orogen in West Amazon Craton based on mapping and U-Pb geochronology. Precambrian Research, 165:120-152.

Schobbenhaus C. \& Brito-Neves B.B. 2003. A geologia do Brasil no Contexto da Plataforma Sul-Americana. In: Bizzi L.A., Schobbenhaus C., Vidotti R.M., Gonçalves J.H. (eds.) Geologia, tectônica e recursos minerais do Brasil: texto, mapas \& SIG. Brasília, CPRM - Serviço Geológico do Brasil, $692 \mathrm{p}$

Schobbenhaus C., Campos D.A., Derze G.R., Asmus H.E. 1984. Geologia do Brasil: Texto explicativo do Mapa Geológico do Brasil e da área oceânica adjacente incluindo depósitos minerais. Escala 1:2.500.000. Brasília, DNPM, 501 p.

Schobbenhaus C., Hoppe A., Lork A., Baumann A. 1994. Idade U/ $\mathrm{Pb}$ do magmatismo Uatumã no norte do Cráton Amazônico, Escudo das Guianas (Brasil): primeiros resultados. In: Congresso Brasileiro de Geologia, Sociedade Brasileira de Geologia, 38:395-397.

Schobbenhaus C., Gonçalves J.H., Santos J.O.S., Abram M.B., Leão Neto R., Matos G.M.M., Vidotti R.M., Ramos M.A.B., Jesus J.D.A. 2004. Carta Geológica do Brasil ao Milionésimo. Sistema de Informações Geográficas. Folhas Boa Vista (NA-20) e Roraima (NB-20). Escala $1: 1,000,000$, CPRM 
Silver P.G. \& Behn D. 2008. Intermittent plate tectonics. Science, 319:85-88

Smirnov A.V., Evans D.A.D., Ernst R.E., Söderlund U., Li A.X. 2013. Trading partners: Tectonic ancestry of southern Africa and Western Australia, in Archean supercratons Vaalbara and Zimgarn. Precambrian Research, 224:11-22.

Swanson-Hysell N.L., Maloof A.C., Weiss B.P., Evans D.A. 2009. No asymmetry in geomagnetic reversals recorded by 1.1-billion-yearold Keweenawan basalts. Nature Geoscience, 2:713-717.

Tamura LN., D’Agrella-Filho M.S., Trindade R.I., Teixeira W., Ruiz A.S. 2013. Estudo paleomagnético do enxame de diques máficos Rancho de Prata. In: $13 \circ$ Simpósio de Geologia da Amazônia, Anais, Belém, Pará, CDR (21), 4 p.

Tassinari C.C.G. \& Macambira M.J.B. 1999. Geochronological provinces of the Amazonian Craton. Episodes, 22:174-182.

Tassinari C.C.G. \& Macambira M.J.B. 2004. A evolução tectônica do Cráton Amazônico. In: Mantesso-Neto V., Bartorelli A., Dal Ré Carneiro C., Brito-Neves B.B. (eds.) Geologia do Continente SulAmericano: Evolução da obra de Fernando Flávio Marques de Almeida. São Paulo, Beca, p. 471-485.

Tassinari C.C.G., Cordani U.G., Nutman A.P., van Schmus W.R., Bettencourt J.S., Taylor P.N. 1996. Geochronological systematics on basement rocks from the Rio Negro-Juruena Province (Amazon C Rio Alegre Terrainon) and tectonic implications. International Geology Review, 38:1161-1175.

Tassinari C.C.G., Bettencourt J.S., Geraldes M.C., Macambira M.J.B., Lafon J.M. 2000. The Amazonian Craton. In: Cordani U.G., Milani E.J., ThomazFilho A., Campos D.A. (eds.) Tectonic Evolution of South America. Rio de Janeiro, 31st International Geological Congress, p. 41-95.

Teixeira W., Geraldes M.C., Matos R., Ruiz A.S., Saes G., Vargas-Mattos G. 2010. A review of the tectonic evolution of the Sunsas belt, SW portion of the Amazonian Craton. Journal of South American Earth Sciences, 29:47-60.

Teixeira W., Geraldes M.C., D’Agrella-Filho M.S., Santos J.O.S., Barros M.S.S., Ruiz A.S., Corrêa da Costa P.C. 2011. Mesoproterozoic juvenile mafic-ultramafic magmatism in the SW Amazonian Craton (Rio Negro-Juruena province): SHRIMP U-Pb geochronology and Nd-Sr constraints of the Figueira Branca Suite. Journal of South American Earth Sciences, 32:309-329.

Teixeira W., Ernst E.E., Hamilton M., Lima G., Ruiz A.S., Geraldes M.C. 2016. Widespread ca. $1.4 \mathrm{Ga}$ intraplate magmatism and tectonics in a growing Amazonia. GFF, 138(1):241-254.

Théveniaut H., Delor C., Lafon J.M., Monié P., Rossi P., Lahondère D. 2006. Paleoproterozoic (2155-1970 Ma) evolution of the Guiana Shield (Transamazonian event) in the light of new paleomagnetic data from French Guiana. Precambrian Research, 150:221-256.

Tohver E. \& Trindade R.I.F. 2014. Comment on was there an ediacaran clymene ocean in central South America by Cordani UG and others. American Journal of Science, 314(3):805-813.

Tohver E., van der Pluijm B., van der Voo R., Rizzotto G., Scandolara J.E. 2002. Paleogeography of the Amazon craton at 1.2 Ga: early Grenvillian collision with the Llano segment of Laurentia. Earth and Planetary Science Letters, 199:185-200.

Tohver E., van der Pluijm B., Mezger K., Essene E., Scandolara J. 2004a. Significance of the Nova Brasilândia metasedimentary belt in western Brazil: redefining the Mesoproterozoic boundary of the Amazon Craton. Tectonics, 23(6):TC6004:1-20.

Tohver E., Bettencourt J.S., Tosdal R., Mezger K., Leite W.B., Payolla B.L. 2004b. Terrane transfer during the Grenville orogeny: tracing the Amazonian ancestry of southern Appalachian basement through $\mathrm{Pb}$ and $\mathrm{Nd}$ isotopes. Earth and Planetary Science Letters, 228:161-176.
Tohver E., D’Agrella-Filho M.S., Trindade R.I.F. 2006. Paleomagnetic record of Africa and South America for the 1200-500 Ma interval, and evaluation of Rodinia and Gondwana assemblies. Precambrian Research, 147:193-222

Tohver E., Trindade R.I.F., Solum J.G., Hall C.M., Riccomini C., Nogueira A.C. 2010. Closing the Clymene ocean and bending a Brasiliano belt: Evidence for the Cambrian formation of Gondwana, southeast Amazon Craton. Geology, 38:267-270.

Tohver E., Cawood P.A., Rossello E.A., Jourdan F. 2012. Closure of the Clymene Ocean and formation of West Gondwana in the Cambrian: Evidence from the Sierras Australes of the southernmost Rio de la Plata craton, Argentina. Gondwana Research, 21:394-405.

Torsvik T.H. \& Smethurst M.A. 1999. Plate tectonic modelling: virtual reality with GMAP1. Computers \& Geosciences, 25:395-402.

Trindade R.I.F., Font E., D’Agrella-Filho M.S., Nogueira A.C.R., Riccomini C. 2003. Amazônia at low-latitude by the end of the 600 Ma Puga glaciation. Terra Nova, 15:441-446.

Trindade R.I.F., D’Agrella-Filho M.S., Epof I., Brito-Neves B.B. 2006. Paleomagnetism of the Early Cambrian Itabaiana mafic dykes, NE Brazil, and implications for the final assembly of Gondwana and its proximity to Laurentia. Earth and Planetary Science Letters, 244:361-377.

Trompette R. 1994. Geology of Western Gondwana (2000-500 Ma). Pan-African-Brasiliano aggregation of South America and Africa. A.A. Balkema, Rotterdam, Brookfield, 366 p.

Trompette R. 1997. Neoproterozoic ( 600Ma) aggregation of Western Gondwana: a tentative scenario. Precambrian Research, 82:101-112.

Valdespino O.E.M. \& Alvarez V.C. 1997. Paleomagnetic and rock magnetic evidence for inverse zoning in the Parguaza batholith (southwestern Venezuela) and its implications about tectonics of the Guyana shield. Precambrian Research, 85:1-25.

Vanderhaeghe O., Ledru P., Thiéblemeont D., Egal E., Cocherie A., Tegyey M., Milesi J.P. 1998. Contrasting mechanism of crustal growth Geodynamic evolution of the granite-greenstone belts of French Guiana. Precambrian Research, 85:1-25.

Van der Voo R. 1990. The reliability of paleomagnetic data. Tectonophysics, 184:1-9.

Van Der Voo R. \& Torsvik T.H. 2012. The history of remagnetization of sedimentary rocks: deceptions, developments and discoveries. Geological Society, London, Special Publications, 371:23-53.

Veikkolainen T., Heinonen A., Pesonen L.J., Fraga L.M., Rämö O.T., Dall'Agnol R. 2011. Mucajaí-kompleksin (Pohjois-Amazonia, Brasilia) paleomagnetismista. XXV GEOFYSIIKAN PÄIVÄT, 121-124.

Veldkamp J., Mulder F.G., Zijderveld J.D.A. 1971. Palaeomagnetism of Suriname dolerites. Physics of the Earth and Planetary Interiors, 4:370-380.

Vigneresse J.L. 2005. The specific case of the Mid-Proterozoic rapakivi granites and associated suite within the context of the Columbia Supercontinent. Precambrian Research, 137:1-34.

Wegener A. 1912. The origin of the continents. Petermanns Geographische Mitteilungen, 58(1):185-195, 253-256, 305-309.

Weil A.B., van der Voo R., Niocaill C.M., Meert J.G. 1998. The Proterozoic supercontinent Rodinia: paleomagnetically derived reconstructions for 1100 to $800 \mathrm{Ma}$. Earth and Planetary Science Letters, 154:13-24.

Williams S., Müller R.D., Landgrebe T.C.W., Whittaker J.M. 2012. An open-source software environment for visualizing and refining plate tectonic reconstructions using high resolution geological and geophysical data sets. GSA Today, 22(4/5):4-9. 
Wingate M.T.D., Pisarevsky S.A., Gladkochub D.P., Donskaya T.V. Konstantinov K.M., Mazukabzov A.M., Stanevich A.M. 2009. Geochronology and paleomagnetism of mafic igneous rocks in the Olenek Uplift, northern Siberia: implications for Mesoproterozoic supercontinents and paleogeography. Precambrian Research, 170:256-266.

Xu H., Yang Z., Peng P., Meert J.G., Zhu R. 2014. Paleo-position of the North China craton within the Supercontinent Columbia: Constraints from new paleomagnetic results. Precambrian Research, 255:276-293.

Yakubchuk A. 2010. Restoring the supercontinent Columbia and tracing its fragments after its breakup: A new configuration and a Super Horde hypothesis. Journal of Geodynamics, 50:166-175.

Zhang S., Li Z.X., Evans D.A.D., Wu H., Li H., Dong J. 2012. PreRodinia supercontinent NUNA shaping up: A global synthesis with new paleomagnetic results from North China. Earth and Planetary Science Letters, 353-354:145-155.
Zhao G., Cawood P.A., Wilde S.A., Sun M. 2002. Review of global 2.1-1.8 Ga orogens: implications for a pre-Rodinia supercontinent. Earth-Science Reviews, 59:125-162.

Zhao G., Sun M., Wilde S.A., Li S. 2003. Assembly, accretion and breakup of the Paleo-Mesoproterozoic Columbia Supercontinent: records in the North China Craton. Gondwana Research, 6:417-434.

Zhao G., Sun M., Wilde S.A., Li S. 2004. A Paleo-Mesoproterozoic supercontinent: assembly, growth and breakup. Earth-Science Reviews, 67:91-123.

Zhao G., Sun M., Wilde S.M., Sanzhong L., Zhang J. 2006. Some key issues in reconstructions of Proterozoic supercontinents. Journal of Asian Earth Sciences, 28:3-19.

Available at www.sbgeo.org.br 